ARTICLES

\title{
The Legacy of Industrial Pluralism: The Tension Between Individual Employment Rights and the New Deal Collective Bargaining System
}

\author{
Katherine Van Wezel Stone $\dagger$
}

As labor unions are declining, ${ }^{1}$ so too is the legal framework that has governed labor relations in the United States since the New Deal. In the past decade, the New Deal labor laws, ${ }^{2}$ which were intended to create collective rights for workers and to empower organized labor, have been undermined through a series of judicial and administrative decisions. ${ }^{3}$ The underlying premises

$\dagger$ Professor of Law, Cornell Law School; and Professor, Cornell School of Industrial and Labor Relations. This article is 1992 by Katherine Van Wezel Stone. The author would like to thank participants in workshops at The University of Chicago, Cornell University, New York University, the University of Southern California, the State University of New York (Buffalo), and the University of Toronto Law Schools, as well as participants in workshops at the Cornell School of Industrial and Labor Relations, the Political Science Department of Yale University, and the Graduate Center of the City University of New York. She would also like to extend particular thanks to Cass Sunstein, Steve Shiffrin, Anne-Marie Burley, Nick Salvatore, Jim Atleson, Stewart Schwab, Roy Adams, Greg Alexander, Bob Hillman, and Gerd Korman for insightful suggestions, and to Philip Douglass, Daniel Shacknai, and Suzanne Woodland for exceptional research assistance. Finally, the author thanks the Fund for Labor Relations Research, which provided partial funding for this project.

${ }^{1}$ Union membership has declined from approximately 25 percent of the nonagricultural workforce in 1980 to 16.3 percent in 1990. See notes 6-7 and accompanying text (Table I).

2 The most important federal labor laws enacted in the New Deal period were the National Labor Relations Act, Pub L No 49 Stat 449 (1935), codified at 29 USC $\S 151$ et seq (1988) (the "NLRA"), and the Norris-La Guardia Act, Pub L No 47 Stat 70 (1932), codified at 29 USC $\S \S 101$ et seq (1988).

${ }^{3}$ See generally Lee Modjeska, The Reagan NLRB, Phase I, 46 Ohio St L J 95, 130-31 (1985) ("In my view . . . the [Reagan Era] Board reversals are of major import and pro- 
and assumptions of the labor relations system have also been the subject of intense scholarly attack. ${ }^{4}$ Overall, it appears that the era of collective bargaining that was born in the New Deal and that blossomed in the post-war decades is coming to an end.

With the old system of collective bargaining fading away, something new is emerging to take its place. In the past decade, state legislatures and courts have created a plethora of new employment rights for individual workers-rights not to be fired abusively, rights for privacy on the job, rights to be free of drug testing, rights to be free of sexual harassment, rights for whistleblowers, and so forth. Paradoxically, these new individual employee rights are emerging just as labor's collective rights are waning. Do these new individual rights signify a fundamental change in the system of legal regulation of employment in this country? Or are they merely an accretion to, or embellishment of, the New Deal system of collective bargaining? This question is important if we want to understand what is happening to the law governing labor relations and influence its future course. If the New Deal system of collective bargaining is collapsing, and if a new system is emerging, it is important to recognize that fact, and initiate a public debate about the strengths and weaknesses of the new system, the old system, and others that might be imagined.

There is a plausible argument that the newly emerging individual employment rights are an evolution of the pre-existing system of collective bargaining. After all, the new individual employment rights seem perfectly compatible with the system of

foundly alter the preexisting balance of labor management relations . . . ."); James B. Atleson, Reflections on Labor, Power, and Society, 44 Md L Rev 841, 871 (1985) (arguing that recent Board and Supreme Court decisions have weakened union power, and that these decisions reflect, and further, the growing imbalance of power between unions and corporate structures); William B. Gould IV, Some Reflections on Fifty Years of the National Labor Relations Act: The Need for Labor Board and Labor Law Reform, 38 Stan L Rev 937, 939 (1986) (arguing that the Reagan Board has exhibited a "pronounced hostility to unions and collective bargaining"). See also Katherine Van Wezel Stone, Labor and the Corporate Structure: Changing Conceptions and Emerging Possibilities, 55 U Chi L Rev 73 (1988) (detailing recent legal decisions that have restricted the power of unions to influence strategic corporate decisionmaking).

- See, for example, Richard A. Epstein, A Common Law for Labor Relations: A Critique of the New Deal Labor Legislation, 92 Yale L J 1357 (1983); Charles Fried, Individual and Collective Rights in Work Relations: Reflections on the Current State of Labor Law and Its Prospects, 51 U Chi L Rev 1012 (1984); Katherine Van Wezel Stone, The Post-War Paradigm in American Labor Law, 90 Yale L J 1509 (1981); Karl E. Klare, Judicial Deradicalization of the Wagner Act and the Origins of Modern Legal Consciousness, 1937-1941, 62 Minn L Rev 265 (1978). See also James B. Atleson, Values and Assumptions in American Labor Law (Massachusetts, 1983). 
collective bargaining. Indeed, they might enhance labor's strength in the workplace by setting a floor above which unions negotiate. They might also strengthen unions by removing the more general issues from the bargaining table, thus permitting unions to focus on those issues of particular concern to each workplace. This more finely-tuned form of bargaining could strengthen loyalty at the local level and thereby create stronger labor organizations. Greater individual employment rights might also remove sources of conflict within unions. Externally imposed employment terms represent tradeoffs made by a legislature or court, rather than by unions-tradeoffs between the young and the old, the black and the white, and so forth. Thus they spare unions the potentially divisive effects of making such decisions themselves.

However, despite the variety of ways in which external employment rights could be benign or even beneficial to organized labor, the rise of individual employment rights has not had that effect. Rather, there is a tension between the new individual employment rights and the New Deal system of collective bargaining, a tension that means, concretely, that organized workers do not share in the benefits of the new employment rights. Examining why this is so will enable us to see that the newly emerging system is a distinct and separate form of legal regulation. And recognizing that reality will enable us to confront the normative issue: What system of legal rules is best suited for regulating employment relations?

I begin in Section I with a description of union decline and a discussion of several theories that have been offered to explain it. In Section II, I summarize the developments of the past decade in labor and employment law in order to illustrate in more detail what I described above: that the National Labor Relations Board (the "NLRB") and the courts in recent years have diminished the ability of unions to provide job security for their members while, at the same time, state legislatures have begun providing some modicum of job security for individual employees.

In Section III, I ask: What has the rise of individual rights meant for unionized workers? The answer lies in the labor law doctrine of $\S 301$ preemption. Section 301 of the Labor Management Relations Act grants federal jurisdiction over suits for violations of collective bargaining agreements. Under $\S 301$, courts determine whether the collective bargaining agreement preempts claims an employee brings under external statutory or common law rights. I show that by means of a broad $\S 301$ preemption doctrine, courts have erected a rigid barrier between collectively bargained rights 
and individual employment rights. As a result, unionized workers now have, in many respects, fewer employment rights than do their nonunion brothers and sisters.

In Section IV, I argue that the reason the courts have adopted such a broad $\S 301$ preemption doctrine is the conception of collective bargaining that has dominated judicial and scholarly thinking about collective bargaining in the post-war era. That particular conception of labor relations, which I call "industrial pluralism," is based on private bargaining and private contractual rights. Its reasoning and rhetoric resists the injection of statutory or judicially-created employment rights into the workplace, promoting instead a vision of the workplace as a self-sufficient realm.

Finally, in Section V, I discuss three normative and policy questions that the analysis raises: First, is the emerging system of individual employment rights preferable to the New Deal system of collective bargaining? Second, are there forms of collective bargaining that do not insulate the unionized workplace from external sources of rights? And third, does the $\S 301$ preemption analysis and legal incompatibility between individual and collective rights play a role in union decline? I then conclude by arguing that the individual rights model of employment relations does not provide an adequate substitute for collective bargaining, and that a new model of collective workplace rights is necessary if we are to promote workplace justice and protect workers' standards of living.

\section{UNion DeCLINE}

No discussion of modern labor relations can ignore the fact of union decline. Between 1980 and 1990, union membership declined from almost twenty-five percent of the nonagricultural work force to less than seventeen percent. The following table traces union decline both in absolute numbers and as a percentage of the nonagricultural workforce:

\footnotetext{
s Stone, 90 Yale L J at 1514-17 (cited in note 4); Katherine Van Wezel Stone, Reenvisioning Labor Law: A Response to Professor Finkin, $45 \mathrm{Md}$ L Rev 978, 978-80 (1986).
} 


\section{TABLE I DECLINING UNION MEMBERSHIP ${ }^{\circ}$}

\begin{tabular}{ccccc} 
& \multicolumn{2}{c}{$\begin{array}{c}\text { Absolute Number of } \\
\text { Workers in Unions }\end{array}$} & \multicolumn{2}{c}{$\begin{array}{c}\text { Union Members as Percentage } \\
\text { of Non-Agricultural Workforce }\end{array}$} \\
$\underline{\text { Year }}$ & $\underline{\text { Total }}$ & $\underline{\text { \% Change }}$ & $\underline{\%}$ & $\underline{\text { \% Change }}$ \\
1950 & 14,267 & - & $31.5 \%$ & - \\
1960 & 17,049 & $19.5 \%$ & $31.4 \%$ & $(0.3 \%)$ \\
1970 & 19,381 & $13.7 \%$ & $27.3 \%$ & $(13.1 \%)$ \\
1980 & 22,366 & $15.4 \%$ & $24.7 \%$ & $(9.5 \%)$ \\
1990 & 16,740 & $(25.2 \%)$ & $16.1 \%$ & $(34.8 \%)$
\end{tabular}

Note that the decade of the 1980s saw a marked hastening of the rate of decline. ${ }^{7}$ Indeed, the declining rate in the $1980 \mathrm{~s}$ is even more dramatic for private sector unionism. Between 1983 and 1989, union membership declined from 16.8 percent of the private, nonagricultural workforce to 12.4 percent $^{8}-$ an overall decline of more than twenty-five percent.

There are many theories to explain union decline. One theory, the employer-opposition theory, posits that unions have declined as a consequence of intensified union avoidance strategies by employers. This theory has several variations. One variation stresses the fact that, in the 1970s, the difference between union and non-

- 1950-70 data from Michael Goldfield, The Decline of Organized Labor in the United States 10 Table I (Chicago, 1987); 1980 data from id at 11 Table II; 1990 data from 38 Employment \& Earnings 228-29, Tables 57 \& 58 (Jan 1991).

3 "During the 1980s, . . . private sector unions experienced one of their most severe drops in membership in United States history ...." Leo Troy, Will a More Interventionist NLRA Revive Organized Labor?, 13 Harv J L \& Pub Pol 583, 607 (1990).

Professor Michael Goldfield, in his impressive book, The Decline of Organized Labor (cited in note 6), argues that union decline is nothing new: There has been a steady and constant decline in the percentage of the workforce unionized from the mid-1950s until 1980. Professor Goldfield attributes this trend primarily to class forces, growing management resistance, union passivity, and pro-employer public policy choices. Id at 180-217. Thus he discounts explanations that are based on phenomena such as short-term changes in the demographics of the workforce or employer attitudes. However, while Goldfield does demonstrate a long-term, slow union decline, he does not address the precipitous, almost free-fall decline that occurred in the 1980s. Most of his data predate the 1980s, and his data for the years 1980-85 suggest a new, steeper phase of union decline. Id at 16 (Table 3). To understand the dramatic decline of the past decade, we need a theory that at least partially disentangles it from the longer-run steady decline that Goldfield documents.

s Statistical Abstract of the United States: 199142 (Table 697) (GPO, 1991). See also Troy, 13 Harv J L \& Pub Pol at 592-94 (cited in note 7). 
union wages was at an all-time high. Therefore employers had powerful financial incentives to resist unions where they did not exist and to eliminate them where they did. ${ }^{9}$ In other words, unions effectively priced themselves out of the market.

Another variation of the employer-opposition theory suggests that the Reagan Administration's treatment of the air traffic controllers' strike and similar actions encouraged employers to resist their unions. ${ }^{10}$ In this view, employers have always been antiunion, and the shift in official attitudes in the past decade emboldened them to act on their predilections.

In yet another variation of the employer-opposition school of thought, some scholars attribute union decline to an increase in unlawful employer behavior during election campaigns and the inability of the NLRB effectively to police and remedy employers' unfair labor practices. ${ }^{11}$ The most prominent spokesman of this viewpoint is Professor Paul Weiler of the Harvard Law School. ${ }^{12}$

Another group of scholars has attempted to explain union decline with a union-complacency theory. According to this theory,

- See, for example, Robert J. Flanagan, NLRA Litigation and Union Representation, 38 Stan L Rev 957, 984-85 (1986).

10 See, for example, Charles McDonald, U.S. Union Membership in Future Decades: A Trade Unionist's Perspective, 31 Indus Rel 13, 15 (1992) (attributing the precipitous drop in union membership in the 1980s to President Reagan's actions); Michael J. Goldberg, Cleaning Labor's House: Institutional Reform Litigation in the Labor Movement, 1989 Duke L J 903, 1002 (hypothesizing the adverse effect of improper governmental intervention on the labor movement); David L. Gregory, Book Review, 53 Geo Wash L Rev 680, 681-83 (1985) (arguing that the Administration's treatment of the PATCO strike and its reshaping of the NLRB have combined with recent Supreme Court decisions to create an atmosphere hostile to unions). See generally Bernard D. Meltzer and Cass R. Sunstein, Public Employee Strikes, Executive Discretion, and the Air Traffic Controllers, 50 U Chi L Rev 731 (1983) (analyzing air traffic controllers' strike and its legal consequences).

${ }^{11}$ See, for example, Modjeska, 46 Ohio St L J at 131 (cited in note 3) (recent NLRB decisions reflect a "substantial deregulation of employer conduct with a concomitant, potential disenfranchisement of employee rights and interests"); Paul Alan Levy, The Unidimensional Perspective of the Reagan Labor Board, 16 Rutgers L J 269, 269-70 (1985) ("II]n the three years since President Reagan's appointees began to join the Board, there has been an unprecedented assault on this country's labor laws . . . led by . . . Board members who are wholly unsympathetic to the [NLRA's] purposes.").

12 Paul Weiler, Promises to Keep: Securing Workers' Rights to Self-Organization Under the NRLA, 96 Harv L Rev 1769 (1983) (arguing that the failure of the NLRB to police and remedy violations of $\S 8(\mathrm{a})(3)$ of the NLRA is a major factor in union decline). However, some scholars have disputed Weiler's data and conclusions. See Robert J. LaLonde and Bernard D. Meltzer, Hard Times for Unions: Another Look at the Significance of Employer Illegalities, 58 U Chi L Rev 953, 954-55 (1991), to which Professor Weiler responded powerfully in Hard Times for Unions: Challenging Times for Scholars, $58 \mathrm{U}$ Chi L Rev 1015 (1991). See also Leo Troy, Market Forces and Union Decline: A Response to Paul Weiler, 59 U Chi L Rev 681 (1992). For a critique of employer-opposition explanations for union decline generally, see Troy, 13 Harv J L \& Pub Pol at 590-95 (cited in note 7). 
union decline is a result of the failure of unions to adjust to a changing economy. Some theorists of this school emphasize the failure of unions to aggressively organize new members. ${ }^{13}$ Some also cite shifts in the composition of the workforce from white males to minorities and women-groups to which unions have not traditionally appealed. ${ }^{14}$ Still others of this school stress the shift in the economy away from blue collar manufacturing jobs, which had been heavily unionized, toward white collar and service jobs, where unions traditionally have been weak. ${ }^{15}$

No doubt, the employer-opposition and the union-complacency theories each tell part of the story, but neither can fully account for the phenemonon. For example, while increased employer opposition to unions is undoubtedly a factor in union decline, it does not satisfactorily explain why unorganized workers have not made more efforts to unionize in the face of the declining real earnings of the 1980s. ${ }^{16}$ Similarily, union complacency may explain why unions in the older manufacturing sectors are declining, but it does not explain why employees in the new sectors do not unionize. ${ }^{17}$ Furthermore, to attribute union decline to the failure of unions to organize new types of workers in new types of industries is to ignore the facts. To the extent that unions have made gains in recent years, the gains have been among women and minorities, in the service and white collar sectors. Unions have been growing

${ }^{13}$ See, for example, Gregory, 53 Geo Wash L Rev at 681 (cited in note 10).

14 See, for example, Marion Crain, Feminizing Unions: Challenging the Gendered Structure of Wage Labor, 89 Mich L Rev 1155, 1172 (1991) ("the influx of women into the workforce has been cited as a major barrier to union growth"); Theodore J. St. Antoine, Federal Regulation of the Workplace in the Next Half Century, 61 Chi Kent L Rev 631, 645 (1985) (attributing union decline, in part, to the failure of unions to appeal to the young, women, minorities, and white collar workers); Charles B. Craver, The Vitality of the American Labor Movement in the Twenty-First Century, 1983 U Ill L Rev 633, 648-49 (observing the traditional under representation of minorities and women in unions, and emphasizing the need to include these groups); Michael J. Goldberg, Affirmative Action in Union Government: The Landrum-Griffin Act Implications, 44 Ohio St L J 649, 652-66 (1983) (discussing the history of discrimination in the labor movement and proposing the use of affirmative action to increase the representation of minorities and women in union leadership).

${ }^{15}$ See, for example, Gould, 38 Stan L Rev at $942-43$ (cited in note 3) (stressing unions' inability to organize in "high tech" and developing industries); Troy, 13 Harv J L \& Pub Pol at 612-25 (cited in note 7) (describing shifts from manufacturing to producer services).

${ }^{18}$ Despite the unprecedented boom years of the 1980s in the financial and real estate markets, the real wages for production workers in the manufacturing industries declined over $11 \%$ between 1978 and 1988. Statistical Abstract of the United States: 1990 407, Table 668 (GPO, 1990).

${ }_{17}$ Professor Troy points to such structural factors to explain union decline, but does not explain why white collar service workers, or workers in the growing high-tech sector, do not unionize. Troy, 13 Harv J L \& Pub Pol at 612-25 (cited in note 7). 
among public sector employees, hospital workers, retail clerks, and other pink and white collar types of workers. ${ }^{18}$ Thus it is just not true that unions have made no efforts toward those types of workers, nor is it true that unions have had no appeal.

In a recent article, Professor Henry Farber of Princeton University gave a new perspective on union decline. Professor Farber analyzed several studies of worker attitudes toward unions that were conducted between 1977 and $1984 .{ }^{19} \mathrm{He}$ concluded that workers were not unionizing for two reasons. First, there was an increase in job satisfaction among unorganized workers, which Farber attributed not to improvements in their pay or job security, but to their declining expectations. ${ }^{20}$ Second, the number of nonunion workers who perceived that unions were effective in improving wages and working conditions had dropped significantly. ${ }^{21}$ Pro-

18 Between 1983 and 1991, the percentage of union members who are women, blacks, Hispanics, and managerial and professional employees has grown significantly. This can be seen in the following tables, which show that in these categories, union membership has either grown or declined only slightly, while overall union membership has declined substantially. This has resulted in a net percentage increase of total union membership among these groups.

TABLE II

Total Union Membership in Absolute Numbers

$\begin{array}{cccccc} & \text { Total Union } & \text { Women } & \text { Blacks } & \text { Hispanic } & \text { Managerial } \\ 1983 & 17,717 & 5,908 & 2,440 & 1,042 & 3,354 \\ 1991 & 16,568 & 6,138 & 2,425 & 1,275 & 3,802\end{array}$

TABLE III

Composition of Union Membership

$\begin{array}{cccccc} & \text { Total Union } & \text { Women } & \text { Blacks } & \text { Hispanic } & \text { Managerial } \\ 1983 & 100 \% & 33.34 \% & 13.77 \% & 5.88 \% & 18.93 \% \\ 1991 & 100 \% & 37.05 \% & 14.63 \% & 7.69 \% & 22.94 \%\end{array}$

1983 data from 32 Employment \& Earnings 208-09, Tables 52 \& 53 (Jan 1985); 1991 data from 39 Employment \& Earnings 228-29, Tables 57 \& 58 (Jan 1992).

These data suggest that to the extent unions have effectively recruited during the 1980s, it has been among these groups. See also Weiler, $58 \mathrm{U}$ Chi L Rev at 1017 (cited in note 12) ("[S]ince the '50s, unions have also lost major ground within their manufacturing and construction bases while simultaneously achieving major breakthroughs in the public sector, in such quintessentially 'female' service occupations as teaching, nursing, and government clerical work.").

${ }^{19}$ Henry S. Farber, The Recent Decline of Unionization in the United States, 238 Science 915 (Nov 13, 1987).

20 Id at 917-19.

21 Id. One of the studies Farber used was conducted by the Harris Survey in 1984. It concluded that nonunion employees saw unions as "an irrelevant way to solve their work problems." Troy, 13 Harv J L \& Pub Pol at 600 (cited in note 7). Professory Troy also uses this data to argue that employee opposition is, quantitatively, a more significant factor in 
fessor Farber called this a decline in the perception of "union instrumentality." 22 On the basis of a statistical model, Professor Farber concluded that "all of the decline in demand among nonunion workers can be accounted for by the increase in nonunion workers' satisfaction and decrease in perceptions of union instrumentality."23

In short, Farber attributes union decline in large part to declining employee confidence in the power of unions to better wages, job security, and other working conditions. If he is right, the problem of explaining union decline then becomes the problem of determining why the public perception of union effectiveness has changed in recent years.

Many factors, including cultural and economic factors exogenous to the labor relations system, shape public perceptions of union effectiveness. But undoubtedly one of these factors is a decline in actual union effectiveness. The decline in actual union effectiveness cannot summarily be dismissed as simply the natural result of the inherent weakness of unions. Actual union effectiveness is, to a large extent, a product of the legal rules that determine what unions can and cannot do. ${ }^{24}$

For example, some legal rules prevent unions from influencing corporate decisions of importance to their members, such as the rules prohibiting bargaining for work acquisition or bargaining to stop double-breasting. ${ }^{25}$ Other legal rules influence union economic power, by prohibiting secondary boycotts or permitting employers to hire permanent replacements during strikes. ${ }^{26}$ In short, because legal rules define union power and effectiveness, changes in the le-

the decline of private-sector unionism than employer opposition. Id at 599-600. See also Troy, $59 \mathrm{U}$ Chi L Rev at 687-88 (cited in note 12).

${ }^{22}$ Farber, 238 Science at 918 (cited in note 19).

${ }^{23}$ Id at 919.

24 See Stone, $55 \mathrm{U}$ Chi L Rev at 85 \& $\mathrm{n} 43$ (cited in note 3) (discussing labor law rules that regulate labor's and management's power). See also Katherine Van Wezel Stone, Legal Regulation of Economic Weapons: A Comparative Perspective, in Bruno Stein, ed, Proceedings of New York University 43d Annual National Conference on Labor 79, 82-87 (Little, Brown, 1990) (discussing how the legal rules defining labor's right to strike and employers' right to hire replacements shapes each side's economic power). See generally Robert L. Hale, Bargaining, Duress, and Economic Liberty, 43 Colum L Rev 603, 625-28 (1943) (arguing that market power of employees and employers is a function of the compulsion they are legally permitted to bring against the other).

${ }^{25}$ See Stone, 55 U Chi L Rev at 114-17 (cited in note 3).

${ }^{28}$ See Paul C. Weiler, Governing the Workplace 264-73 (Harvard, 1991) (criticizing strike replacement rule and ban on union boycotts of struck product for unduly restricting union bargaining power); Atleson, Values and Assumptions at 19-34 (cited in note 4) (criticizing strike replacement rule on same grounds). 
gal rules governing labor-management relations might partially explain the decline of union effectiveness. Accordingly, to understand union decline, we must examine the content of the labor laws. ${ }^{27}$

The Farber analysis suggests that changes in legal rules may be a factor in union decline. However, the causal arrows go both ways. Legal rules not only determine power, but are also a result of power. When labor is weak, the labor laws are weakened. ${ }^{28}$ The decline of unions and the weakening of the labor laws are mutually reinforcing features of the labor relations landscape.

Part of my task here is to describe some of the legal rules that have compromised union effectiveness in the past decade. My thesis is that to the extent that unions are currently perceived as ineffective, this perception is not fanciful, but rather reflects a reasonably correct understanding of how present labor law doctrine inhibits the power of unions to improve the wages and working conditions of their members.

\section{Recent Developments in American LABOR AND EMPLOYMENT LAW}

The past decade has witnessed a shift from a legal system that protects collective employee rights to one that protects individual employment rights. In this shift, labor relations have been deregulated and then reregulated in an individualized and decentralized fashion. Through a series of judicial and administrative decisions, federal judges and government officials have rewritten the legal rules of collective bargaining-rules that had once protected collective, as opposed to individual, bargaining between employers and employees-so as to strip them of their regulatory bite. At the same time, state legislatures and courts have reregulated labor relations by recognizing new individual employment rights.

27 Professor Weiler has also suggested that the decline of unions can be explained by developments in the labor law. See Weiler, 96 Harv L Rev at 1774-81 (cited in note 12), in which he blames the law governing union organizing campaigns. Specifically, he argues that the dramatic increase in discriminatory discharges during representation campaigns, and the NLRB's ineffectiveness in preventing or remedying such unlawful employer conduct, plays a significant role in union decline. Id. See also Weiler, $58 \mathrm{U}$ Chi L Rev 1015 (cited in note 12) (responding to LaLonde and Meltzer, $58 \mathrm{U}$ Chi L Rev 953 (cited in note 12)). While I find the Weiler thesis compelling, my argument relies less on the law of employee organizing, and more on the law governing the exercise of union power at the bargaining table and in the economic arena.

${ }^{28}$ James B. Atleson, The Prospects for Labor Law Reform, 18 Pol Studies J 364, 371 (1989-90) (unions only achieve favorable legislation when they are "perceived to be vital and troublesome economic actors."). 


\section{A. Federal Deregulation of Collective Labor Rights}

Since the 1930s, the National Labor Relations Act has empowered collective labor action by protecting the right to organize and to strike, and by requiring employers to bargain with their workers' collective representative. ${ }^{29}$ However, in the past decade, the National Labor Relations Board ("NLRB") and the federal courts have reinterpreted the statute so as to dismantle its collective, group-empowering features.

For example, the NLRB has diluted severely the statutory protection of union organizing. ${ }^{30}$ Whereas the NLRB once restricted when an employer could make knowingly false and prejudicial statements about a union during an organizing campaign, it now permits such statements. ${ }^{31}$ Similarily, whereas previously an employer was prohibited from polling employees during union campaigns unless there were strict safeguards to guard against coercion, polls are now generally permitted. ${ }^{32}$ These changes are part of the general trend toward deregulation of union election campaigns. $^{33}$

An even more important aspect of the deregulation of labor relations has occurred in the area of union input into employer strategic-level decisionmaking. ${ }^{34}$ In the past decade, such corporate

29 NLRA $\S \S 7,8(a)$, codified at 29 USC $\S \S 157,158(a)$ (1988). See Stone, 55 U Chi L Rev at 83.84 \& $n 41$ (cited in note 3) (arguing that NLRA \& 8(a) furthers the collectivist aims of the statute).

so See Weiler, 96 Harv L Rev at 1788 (cited in note 12) ("[The NLRA's] remedial philosophy as it has evolved . . . is heavily oriented toward the repair of harm inflicted on individual victims of antiunion activity," instead of toward protecting the employees' collective rights.). See generally Levy, 16 Rutgers $\mathrm{L}$ Rev 269 (cited in note 11).

${ }^{31}$ Midland National Life Insurance Co., 263 NLRB 127, 133 (1982), overruling General Knit of California, Inc., 239 NLRB 619 (1978), and Hollywood Ceramics Co., Inc., 140 NLRB 221 (1962).

${ }^{32}$ Rossmore House, 269 NLRB 1176, 1177-78 (1984) (overruling the per se prohibition of employer polling in favor of evaluating the poll in light of the totality of the circumstances), enforced as Hotel Employees \& Restaurant Union v NLRB, 760 F2d 1006 (9th Cir 1985).

ss See Lechmere, Inc. v NLRB, $112 \mathrm{~S}$ Ct 841 (1992) (permitting employer to prohibit solicitation by non-employee union organizers at employer's parking lot and overturning NLRB's balancing approach to union access cases). See also Weiler, 96 Harv L Rev at 177481 (cited in note 12) (discussing deregulation of election campaigns); Dan C. Heldman, James T. Bennett, and Manuel H. Johnson, Deregulating Labor Relations 49-76 (Fisher Institute, 1981) (calling for the deregulation of union representation elections).

34 The notion of strategic-level corporate decisions is adopted from Thomas A. Kochan, Harry C. Katz, and Robert B. McKersie, The Transformation of American Industrial Relations 15-18 (Basic, 1986), in which they describe a three-tier framework of management decisions. Strategic-level decisions are about "what businesses to invest in, where to locate worksites, whether to make or buy various components, and the organizational arrangements used to carry out basic strategies . . ." Id at 18. 
decisions to engage in mergers, takeovers, or other restructurings have cost union members tens of thousands of jobs. ${ }^{35}$ Despite this impact, the rules of collective bargaining have made it considerably more difficult for unions to protect their membership. The NLRB has exempted employers from the obligation to bargain about most such decisions, adopting instead a policy of deference to the employer's business judgment and business rationality. ${ }^{36}$ In addition, under established doctrine, when a company sells its assets, the purchaser has no obligation to retain the former workforce or to honor labor agreements inherited from the seller. ${ }^{37}$ And if a union negotiates a contractual provision that prevents an employer from

\footnotetext{
35 The AFL-CIO estimates that in the 1980 s its members lost over 80,000 jobs due to takeovers alone, and overall more than 500,000 jobs. Hostile Takeovers, Hearings Before the Senate Committee on Banking, Housing, and Urban Affairs, 100th Cong, 1st Sess 261, 262 (Apr 8, 1987) (statement of Thomas R. Donahue, Secretary-Treasurer, AFL-CIO).

Whether or not takeovers and other corporate restructurings have in fact harmed employees is a subject of debate. There is significant anecdotal evidence, in addition to $\mathrm{Mr}$. Donahue's statement above, that employees have been harmed by corporate takeovers. See, for example, Andrei Shleifer and Lawrence H. Summers, Breach of Trust in Hostile Takeovers, in Alan J. Auerbach, ed, Corporate Takeovers: Causes and Consequences 33, 49-50 (Chicago, 1988) (in the TWA takeover, employee wage reductions amounted to one and onehalf times the takeover premium stockholders received). There is also some empirical evidence that employment levels decrease after management buyouts. See, for example, Steven Kaplan, The Effects of Management Buyouts on Operating Performance and Value, $24 \mathrm{~J}$ Fin Econ 217, 241, Table 9 (1989) (finding that firms experiencing a management buyout between 1980 and 1986 had employment decreases of between $6 \%$ and $12 \%$, when data adjusted according to industry); Krishna G. Palepu, Consequences of Leveraged Buyouts, 27 J Fin Econ 247, 252-53 (1990) ("[B]uyout firms offer lower growth in employment opportunities than other firms in their industries.").

On the other hand, some studies about the impact of takeovers on employees do not support the claim that takeovers cause job loss. See Frank R. Lichtenberg and Donald Siegel, The Effect of Ownership Changes on the Employment and Wages of Central Office and Other Personnel, $33 \mathrm{~J} \mathrm{~L} \&$ Econ 383, 401-02 (1990) (showing that the disparity in employment levels between companies that changed owners and those that did not actually lessened after the change); Charles Brown and James L. Medoff, The Impact of Firm Acquisitions on Labor, in Auerbach, ed, Corporate Takeovers 9, 23 (finding that employment in firms involved in acquisitions declined approximately $5 \%$ after sales of assets, but that employment increased by $9 \%$ after simple sales and by $2 \%$ after simple mergers); Joshua G. Rosett, Do Union Wealth Concessions Explain Takeover Premiums?, $27 \mathrm{~J}$ Fin Econ 263, 279-80 (1990) (finding that firms that experienced hostile takeovers between 1976 and 1987 had a modest wage gain).

${ }^{36}$ See Stone, $55 \mathrm{U}$ Chi L Rev at 86-96 (cited in note 3).

${ }^{37}$ NLRB v Burns International Security Services, 406 US 272, 281-91 (1972) (successor employer not bound by substantive provisions of predecessor's collective bargaining agreement); Howard Johnson Co. v Detroit Local Joint Executive Board, 417 US 249, 260-65 (1974) (same). In the event of a merger, unlike a sale of assets, an employer may have some obligations under the prior collective bargaining agreement. See John Wiley \& Sons, Inc. $v$ Livingston, 376 US 543, 548 (1964) ("[I]n appropriate circumstances, present here, the successor employer may be required to arbitrate with the union under the [predecessor's] agreement.").
} 
transferring unionized work to a non-union subsidiary, it runs a risk of violating the secondary boycott restrictions..$^{38}$ As a result, employer decisions about plant location, introduction of new technology, closing part of an operation, or restructuring of the firm have become practically immune from challenge by unions. ${ }^{39}$

Of these new restrictions on union effectiveness, I will discuss only one-the diminishing scope of the employer's obligation to bargain with its employees, located in $\S 8(a)(5)$ of the NLRA. ${ }^{10}$ It has long been accepted that the statutory duty to bargain only applies to certain areas, called "mandatory subjects of collective bargaining."11 If a subject is a mandatory subject of bargaining, neither employer nor union can make a unilateral alteration until it has bargained with the other to the point of impasse. ${ }^{42}$ And after impasse is reached, only a mandatory subject can be the subject of a protected strike. ${ }^{43}$

There has been a longstanding debate about the scope of mandatory bargaining, particularly as to whether it obligates an employer to bargain over strategic-level decisions that affect jobs-decisions such as plant relocation, partial shut-downs, automation, subcontracting, and so forth. ${ }^{44}$ Some scholars and labor

ss See, for example, D'Amico v Painters District Council 51, 120 Labor Rel Ref Man (BNA) 3473, 3474-80 (D Md 1985) (applying a two-part test to determine whether a "work preservation agreement" is invalid as secondary union activity).

${ }^{39}$ See Stone, $55 \mathrm{U}$ Chi L Rev at 86-120 (cited in note 3).

1029 USC \$ 158(a)(5) ("It shall be an unfair labor practice for an employer to refuse to bargain collectively with the representatives of his employees ....").

${ }^{11}$ NLRB $v$ Wooster Division of Borg-Warner Corp., 356 US 342, 348 (1958).

${ }^{2}$ NLRB v Katz, 369 US 736, 743 (1962); Milwaukee Spring Division of Illinois Coil Spring Co., 268 NLRB 601, 602 (1984), enforced as International Union, UAW v NLRB, 765 F2d 175 (DC Cir 1985).

43 Borg-Warner, 356 US at 349 (neither company nor union can insist to impasse on a nonmandatory bargaining subject). See Michael C. Harper, Leveling the Road from BorgWarner to First National Maintenance: The Scope of Mandatory Bargaining, 68 Va L Rev 1447, 1447 (1982) ("After Borg-Warner, employers and unions [can] not resort to economic pressure to obtain agreement unless the proposal concerns 'wages, hours, [or] other terms and conditions of employment.' "). See also Julius G. Getman, Labor Relations 177 (Foundation, 1978) ("When no collective agreement is in force, the use of economic pressure by an incumbent union in support of its bargaining demands is protected if the subject matter of the demand constitutes a mandatory subject of bargaining.").

4 See William B. Gould IV, The Burger Court and Labor Law: The Beat Goes On-Marcato, 24 San Diego L Rev 51, 64 (1987) (advocating broad scope for mandatory bargaining for decisions affecting job security); Comment, Unfair Labor Practice and Contract Aspects of an Employer's Desire to Close, Partially Close, or Relocate Bargaining Unit Work, 24 Duquesne L Rev 285, 306-08 (1985) (approving trend toward limiting bargaining obligations in the interest of facilitating free flow of capital essential to economic growth); James B. Atleson, Management Prerogatives, Plant Closings, and the NLRA, 11 NYU Rev L \& Soc Change 83, 104-05 (1982-83) (advocating broad scope for mandatory bargaining over employer capital decisions); Note, Partial Closings: The Scope of an Em- 
union activists have argued that, if there is no obligation for management to bargain over those decisions most important to workers, then collective bargaining is not true joint decisionmaking. ${ }^{45}$

Until 1981, it was generally believed that the bargaining obligation was broad, and that the realm of joint decisionmaking was expanding. ${ }^{46}$ Then in 1981, the Supreme Court declared that the scope of bargaining was quite limited, and did not extend to most employer investment decisions. In First National Maintenance Corp. $v N L R B$, the Supreme Court held that an employer was not required to bargain about a decision to close part of its operation. ${ }^{47}$ In setting forth its reasons, the Court introduced a balancing test for determining the scope of mandatory bargaining: When making decisions that have a direct impact on employment security, management is required to bargain "only if the benefit, for labor management relations and the collective-bargaining process, outweighs the burden placed on the conduct of the business." 48

There has been considerable disagreement about what the First National Maintenance balancing test means. ${ }^{49}$ However, the

ployer's Duty to Bargain, 61 BU L Rev 735, 763-72 (1981) (advocating broad duty to bargain in partial closing situations); Robert J. Rabin, Fibreboard and the Termination of Bargaining Unit Work: The Search for Standards in Defining the Scope of the Duty to Bargain, 71 Colum L Rev 803, 827-36 (1971) (suggesting guidelines for restricting duty to bargain about capital decisions); Thomas J. Schwarz, Plant Relocation or Partial Termination-The Duty to Decision-Bargain, 39 Fordham L Rev 81, 100-02 (1970) (advocating limiting bargaining obligation in relocation and partial closing cases to situations where employer proposes to substitute unit workers with non-unit workers); Note, Labor Law Problems in Plant Relocation, 77 Harv L Rev 1100, 1103-06 (1964) (proposing restricting duty to bargain about relocation decisions). See also Michael L. Wachter and George M. Cohen, The Law and Economics of Collective Bargaining: An Introduction and Application to the Problems of Subcontracting, Partial Closure, and Relocation, $136 \mathrm{U} \mathrm{Pa} \mathrm{L} \mathrm{Rev}$ 1349,1352 (1988) (proposing efficiency criteria for evaluating capital mobility decisions).

${ }^{45}$ See Atleson, 11 NYU Rev L \& Soc Change at 107-08 (cited in note 44); Gould, 24 San Diego L Rev at 61-64 (cited in note 44). See also Atleson, $44 \mathrm{Md} \mathrm{L} \mathrm{Rev} \mathrm{at} \mathrm{845-47} \mathrm{(cited}$ in note 3); Stone, 90 Yale L J at $1558-59$ (cited in note 4).

${ }^{48}$ Borg-Warner, 356 US at 358 (Harlan concurring) ("Provisions which two decades ago might have been thought to be the exclusive concern of labor or management are today commonplace in such agreements."). See also Stone, 55 U Chi L Rev at 88 \& nn 51-53 (cited in note 3) (referring to pre-1980 belief in the infinite expandability of bargaining topics).

4752 US 666, 686 (1981). Much earlier the Supreme Court made it clear that an employer had no obligation to bargain about a decision to go out of business altogether. Textile Workers Union v Darlington Mfg. Co., 380 US 263, 273-74 (1965).

${ }^{48}$ First National Maintenance, 452 US at 679.

49 The NLRB attempted to interpret the test in Otis Elevator Co., 269 NLRB 891 (1984). Rather than achieving clarity, however, the NRLB split three ways. The plurality said that First National Maintenance meant that an employer had to bargain when its decision turned on labor costs rather than on a change in the scope and direction of the enterprise. Id at 893. A concurring opinion said that an employer was obligated to bargain when the decision turned on labor costs and the potential benefit from bargaining out- 
NLRB and the courts have agreed that an employer has no obligation to bargain about a decision that would fundamentally change the scope or direction of the enterprise. ${ }^{\text {so }}$ Similarily, they agree that decisions made out of a concern for economic factors are exempt from the bargaining obligation. ${ }^{51}$ Decisions concerning takeovers, mergers, or other transformations in the corporate identity fall into these excluded categories. Thus, for most strategic-level corporate decisions that threaten jobs, there is no legal bargaining obligation that might enable unions to protect employees at the time such decisions are made. ${ }^{52}$ The recent reformulation of the

weighed the costs to the employer of engaging in bargaining. Id at 897. A dissenting opinion said that an employer should be required to bargain for any decision that turned on overall costs, because in that case labor costs would be a part of the employer's overall equation. Id at 900-01. Recently the NLRB reinterpreted the First National Maintenance test in Dubuque Packing Co., 137 Labor Rel Ref Man (BNA) 1185, 1991 NLRB LEXIS 750, in which the NLRB repudiated all three of the tests in Otis Elevator, and announced yet another interpretation of First National Maintenance. 1991 NLRB LEXIS at *19-*20 \& n 8. See note 51 .

so Dubuque Packing Co., 1991 NLRB LEXIS at *27; Arrow Automotive Industries v $N L R B, 853$ F2d 223, 225-27 (4th Cir 1988).

${ }^{81}$ In Dubuque Packing, the NLRB announced a new two-part test to determine the scope of mandatory bargaining in cases concerning a plant relocation: "Initially, the burden is on the General Counsel to establish that the employer's decision involved a relocation ... unaccompanied by a basic change in the nature of the employer's operation. If the General Counsel successfully carries his burden in this regard, he will have established prima facie that the employer's relocation decision is a mandatory subject of bargaining." 1991 NLRB LEXIS at *27. Then the employer can attempt to rebut the prima facie case by showing that the work at the new location is significantly different from that at the former location, or that all work at the former location was to be discontinued. Id. Alternatively, the employer may show, in defense, that labor costs were not a factor in the decision to relocate, or that, even if labor costs were a factor, "the union could not have offered labor cost concessions that could have changed the employer's decision to relocate." Id at *27-*28.

This new test for determining the scope of bargaining, like the Otis Elevator test and the First National Maintenance test itself, retains the notion that an employer's marketbased decisions are shielded from a bargaining obligation. However, Dubuque Packing shifts the burden of proof on the issue of the employer's motivation.

${ }_{82}$ When the labor law does not impose an obligation on an employer to bargain about a particular decision, it still imposes an obligation to bargain about the effects of the decision on the workforce. First National Maintenance, 452 US at 677-78 n 15. However, there is disagreement among scholars as to the actual scope of the requirement to bargain about effects. Compare Thomas C. Kohler, Distinctions Without Differences: Effects Bargaining in Light of First National Maintenance, 5 Indus Rel L J 402, 415 (1983) (courts have interpreted effects bargaining obligation broadly), with Wilbur Daniels and Seth Kupferberg, Sale of Assets, Mergers, and Acquisitions: A Union View, in Samuel Estreicher and Daniel G. Collins, eds, Labor Law and Business Change: Theoretical and Transactional Perspectives 185, 190-91 (Quorum, 1988) (courts and NLRB have been reluctant to require broad effects bargaining).

Effects bargaining usually takes place within a short time after the employer has made and implemented a decision, when the union no longer has leverage to protect its members. If an employer is found to have violated its obligation to engage in effects bargaining, the courts and the NLRB remedy the violation by requiring the employer to give limited back 
scope of the bargaining obligation effectively insulates decisions based on overall profitability, efficiency, or other such marketbased factors from the bargaining obligation.

The doctrinal development in the law of mandatory bargaining reflects the trend toward deregulation of labor relations in the 1980s. Deregulation does not merely mean the repeal of regulation; it also means the reinterpretation of regulation in such a way that it loses its regulatory bite. ${ }^{53}$ While Congress has not repealed the NLRA, the federal courts and the NLRB have reduced the regime of regulation to a proxy for the market. In those areas in which regulation imposes no other obligations on employers than those imposed by the market, the law has rendered unions superfluous. ${ }^{54}$

pay. The standard formula is back pay for the period from five days after the date of the court or Board order until the time the parties reach either agreement or impasse, not to exceed the time the employee was actually out of work and not to be less than two weeks. Transmarine Navigation Corp., 170 NLRB 389, 390 (1968). In practice, this means that when a violation is found, the employer quickly bargains to impasse and is liable for back pay for merely two weeks. See, for example, Yorke v NLRB, 709 F2d 1138, 1144-46 (7th Cir 1983) (imposing penalty of two weeks back pay under Transmarine formula).

${ }^{83}$ The development in the law of mandatory bargaining has been repeated in other areas. For example, in the area of employer discrimination against union members, what had been a blanket prohibition has now been muted by the addition of a business justification defense. See, for example, Handy Andy Associates, Inc., 277 NLRB 208, 215-17 (1985) (no $\$ 8(a)(3)$ violation for subcontracting decision made when employees refused to abandon union). See generally Stone, 55 U Chi L Rev at 96-102 (cited in note 3) (business justification defense is diluting $\S 8(\mathrm{a})(3)$ protections).

st Professors George Cohen and Michael Wachter have argued that the availability of market rationality as an employer defense is not a retreat from regulation but rather a better understanding of the function of labor regulation. They argue that the law should permit employers to make unfettered business decisions, and that it should only constrain an employer when he is acting opportunistically by trying to appropriate transaction-specific investments from his employees. Wachter and Cohen, $136 \mathrm{U} \mathrm{Pa} \mathrm{L} \mathrm{Rev} \mathrm{at} \mathrm{1415-17} \mathrm{(cited} \mathrm{in}$ note 44). See also George M. Cohen and Michael L. Wachter, Replacing Striking Workers: The Law and Economics Approach, in 43d Annual National Conference on Labor 109 (cited in note 24).

This argument ascribes to unions, or to the labor law, the limited role of protecting workers against opportunistic employer behavior. However, it is both conceptually and practically difficult to draw the line between profit-maximizing behavior, which Professors Cohen and Wachter would protect, and opportunistic behavior, which they would constrain. Further, it is worth noting that the Cohen/Wachter argument does not distinguish between preventing employer opportunism by legal rules that empower unions and preventing employer opportunism by direct, legislatively-imposed employee safeguards. Under the logic of the Cohen/Wachter argument, unions limit employer opportunism only to the extent that there are no other generally available legal sanctions against unjust dismissal. If so, then legal protection against unjust dismissal would render unions even more superfluous. A more general form of this argument is discussed at notes 243-54 and accompanying text. 


\section{B. State Protection of Individual Employee Rights}

At the same time that the federal courts and the NLRB have undermined the rights of collective labor in the past ten years, state courts and legislatures have initiated a renaissance of rights for individual employees. Until recently, the protections for individual employment rights in the United States have been minimal compared to the extensive protections in Western Europe. ${ }^{\text {s5 }}$ They have been aimed at the margins of economic life, setting only minimum standards for the wage contract, and not otherwise interfering with its terms. For example, until the late 1970s and 1980s, nonunion employers could hire and fire at will, unrestrained by unjust dismissal laws of any sort. In addition, the United States government provides only minimal insurance against unemployment, retirement, or disability, and no universal health insurance at all. Health insurance, when it exists, is provided privately, usually by collective bargaining agreements between individual unions. Compared to the extensive income and job security protections that workers enjoy in most of Europe, American workers exist in an unmediated, unregulated labor market. ${ }^{5 B}$

In the wake of federal cutbacks in measures such as workplace health and safety regulations and affirmative action programs under the Reagan and Bush administrations, state courts and legislatures have become the protectors of the individual employee. This trend is most visible in the area of unjust dismissal. Beginning in the mid-1970s, some state courts began to hold that certain types of dismissals were unlawful, either as offending a public policy or as a breach of an implicit term of an employment contract. ${ }^{57}$ In the 1980s, these isolated decisions became a nationwide trend: Courts in some thirty-nine states adopted some form of common law employee protection against unjust dismissal. ${ }^{58}$ According to Professor Clyde Summers, as of 1988,

ss See Michael Emerson, Regulation or Deregulation of the Labour Market, 32 Eur Econ $\operatorname{Rev} 775,786-800$ (1988) (discussing regulation of dismissals, layoffs, temporary employment, and part-time work in Europe).

s8 Id at 776.

${ }^{87}$ State courts have used various tort and contract theories. See, for example, Monge $v$ Beebe Rubber Co., 114 NH 130, 316 A2d 549 (1974) (employer breached at-will employment contract by firing employee for refusing to date her supervisor); Frampton $v$ Central Indiana Gas Co., 260 Ind 249, 297 NE2d 425 (1973) (employer committed tort by firing employee for filing workers' compensation claim); Nees v Hocks, 272 Or 210, 536 P2d 512 (1975) (employer committed tort by firing employee for serving on jury).

ss Clyde W. Summers, Labor Law as the Century Turns: A Changing of the Guard, 67 Neb L Rev 7, 13-14 (1988). 
courts in thirty-two states ha[d] adopted public policy exceptions [to the at-will rule], eleven states ha[d] applied the covenant of good faith and fair dealing, and twenty-nine states ha[d] used employee handbooks to find contractual limitations on terminations. ${ }^{89}$

In addition, many states have enacted legislation to protect workers against dismissal in a variety of circumstances. For example, twenty-two states make it unlawful to dismiss an employee in retaliation for filing a workers' compensation claim. ${ }^{60}$ Thirty-four states have given legislative protection for whistle-blowers, and forty-two states regulate the administration of employment-related lie detector tests. ${ }^{61}$ The state of Montana has adopted a Comprehensive Unjust Dismissal law that gives workers protection against wrongful dismissal. ${ }^{62}$

The trend of state protection of individual employment rights is evident in other areas as well. Many states have protected the privacy of workers by restricting the use of drug testing in the workplace. ${ }^{63}$ Some states have adopted more stringent protection for the employment rights of minorities than has the federal government, ${ }^{64}$ and some have used their criminal laws to police industrial health and safety violations that the federal authorities have been unwilling to remedy. ${ }^{65}$ In addition, some states have enacted statutes to protect employees in the event of corporate takeovers. ${ }^{66}$

${ }^{59}$ Id (citing Individual Employment Rights Manual, 9A Lab Rel Rptr (BNA) 505: 5152 (Jan 1988)).

Bo Compiled from Individual Employment Rights Manual, 9A Lab Rel Rptr (BNA) 540-92 (1991).

${ }^{81}$ Id. Of these, statutes in nine states give protection only to public employees.

${ }^{62}$ Mont Code Ann §§ 39-2-901 to 39-2-914 (1991).

${ }^{63}$ Scott S. Cairns and Carolyn V. Grady, Drug Testing in the Workplace: A Reasoned Approach for Private Employers, 12 Geo Mason U L Rev 491, 520-30 (1990); Judith M. Janssen, Substance Abuse Testing and the Workplace: A Private Employer's Perspective, 12 Geo Mason U L Rev 611, 636-39 (1990). See generally, 9A Lab Rel Rptr (BNA) at 540-92 (cited in note 60).

${ }^{64}$ See Charles C. Heckscher, The New Unionism: Employee Involvement in the Changing Corporation 160 (Basic, 1988).

${ }^{65}$ See, for example, Comment, State Prosecutions for Safety-Related Crimes in the Workplace: Can D.A.'s Succeed Where OSHA Failed?, 79 Ky L J 139, 140 (1990-91); Comment, State Criminal Prosecutions: Putting Teeth in the Occupational Safety and Health Act, 12 Geo Mason U L Rev 737, 738-39 (1990); Rebecca S. Webber, The OSH Act and State Criminal Law: A Prosecutor's Brief, 25 Crim L Bulletin 234 (1989).

${ }^{68}$ In the $1980 \mathrm{~s}$, more than half of the states enacted statutes that permitted corporate directors to consider the effect of takeovers or mergers on employees. For a list of these stakeholder statutes, see Appendix, 21 Stetson L Rev 279 (1991). See generally Steven M.H. Wallman, The Proper Interpretation of Corporate Constituency Statutes and Formulation of Director Duties, 21 Stetson L Rev 163, 163-65 (1991) (describing statutes); Katherine 
The increased state protection for individual workers in the past decade seems paradoxical in light of the deterioration of the federal protection for collective labor rights. However, the paradox disappears if we see that the emerging regime of individual employee rights represents not a complement to or an embellishment of the regime of collective rights, but rather its replacement. Viewed in this light, the emerging individual rights constitute a new system for organizing labor relations, one that is distinct from and opposed to the New Deal system of collective bargaining.

\section{The Section 301 Preemption Doctrine}

The New Deal system of collective bargaining, as it has been interpreted, is a distinctively privatized system. The aim of the NLRA is to provide a framework within which labor and management can negotiate the terms of their mutual dealings, free from outside interference; it is not to interfere with the substantive outcomes of the bargaining process. ${ }^{67}$ This privatized form of collective bargaining has rendered collective bargaining legally incompatible with the emerging system of individual employment rights. In order to see this dynamic, it is necessary to examine the labor law doctrine of $\S 301$ preemption.

Federal preemption of state statutory and common law is, of course, a fundamental aspect of our federal system. The Supremacy Clause of the U.S. Constitution states that when a federal law and a state law conflict, federal law prevails. ${ }^{68}$ In the labor

Van Wezel Stone, Employees as Stakeholders Under State Nonshareholder Constituency Statutes, 21 Stetson L Rev 45, 45-47 (1991) (same); David Millon, Redefining Corporate Law, 24 Ind L Rev 223, 240-46 (1991) (noting the proliferation of state statutes permitting directors to pursue non-shareholder interests). The Connecticut stakeholder statute goes further than the others by requiring directors to consider employees' interests. See Conn Gen Stat Ann \$ 33-313(e) (West, 1991) ("For purposes of [making decisions with respect to mergers, consolidations, sales of assets, and business combinations with interested shareholders], a director of a corporation ... shall consider ... the interests of the corporation's employees ....").

In addition, two states have enacted statutes that require a corporate purchaser to honor its predecessor's collective bargaining agreement. See 19 Del Code Ann § 706 (1990); Mass Gen Laws Ann ch $149, \S 20 \mathrm{E}$ (West, 1991).

or According to Dean Harry Shulman, the NLRA established a "bare legal framework [that] is hardly an encroachment on the premise that wages and other conditions of employment be left to autonomous determination by employers and labor." Harry Shulman, Reason, Contract, and Law in Labor Relations, 68 Harv L Rev 999, 1000 (1955). See also NLRB $v$ American National Insurance Co., 343 US 395, 402 (1952) ("The [NLRA] does not compel any agreement whatsoever between employees and employers. Nor does the Act regulate the substantive terms governing wages, hours and working conditions which are incorporated in an agreement.").

os The Supremacy Clause provides: 
field, the potential for preemption is particularly vast. Federal labor laws touch on many aspects of labor-management relations and thus potentially preempt many types of state regulations, including state trespass, antitrust, defamation, and property laws. ${ }^{69}$

Section 301 of the Labor Management Relations Act makes collective bargaining agreements enforceable in a federal court.70 Because many state employment rights duplicate, parallel, or implicate aspects of collective bargaining agreements, a $\S 301$ preemption question is presented whenever a unionized employee attempts to vindicate a state-created employment right in a judicial forum. ${ }^{71}$

When a claim is preempted under $\S 301$, there are two practical consequences. First, the Supreme Court has held that any and all claims for breach of a collective bargaining agreement that are even arguably subject to an arbitration clause must be decided in

This Constitution, and the Laws of the United States which shall be made in Pursuance thereof; and all Treaties made, or which shall be made, under the Authority of the United States, shall be the supreme Law of the Land; and the Judges in every State shall be bound thereby, any Thing in the Constitution or Laws of any State to the Contrary notwithstanding.

US Const, Art VI.

69. See, for example, Teamsters Union v Oliver, 358 US 283, 295-97 (1959) (NLRA preempts Ohio antitrust law that would wholly defeat the congressional purposes behind the NLRA). Compare Farmer $v$ United Brotherhood of Carpenters \& Joiners, 430 US 290, 30102 (1977) (NLRA does not preempt tort action in state court by a union member against his union for damages from intentional infliction of emotional distress); Sears, Roebuck \& Co. v San Diego County Dist. Council of Carpenters, 436 US 180, 199-207 (1978) (NLRA does not preempt state jurisdiction over an employer's action to enforce state trespass laws against union picketing).

${ }^{70}$ Section 301 says, in part:

Suits for violation of contracts between an employer and a labor organization representing employees in an industry affecting commerce ... may be brought in any district court of the United States having jurisdiction of the parties, without respect to the amount in controversy or without regard to the citizenship of the parties.

29 USC § 185(a) (1988).

${ }^{11}$ There are many other preemption issues that arise in the course of applying the NLRA in the face of various state laws that affect employment relations. See, for example, San Diego Building Trades Council v Garmon, 359 US 236, 245 (1959) (state court jurisdiction preempted if an activity was arguably prohibited or arguably protected by federal law); Lodge 76, International Ass'n of Machinists $v$ Wisconsin Employment Relations Comm'n, 427 US 132, 149-51 (1976) (state regulation preempted when it interferes with the balance of economic weapons established by Congress, even though federal labor law did not prohibit the regulation). See William B. Gould IV, et al, When State and Federal Laws Collide: Preemption-Nightmare or Opportunity?, 9 Indus Rel L J 4, 5-6 (1987).

Here I am only focusing on one type of preemption-preemption of state laws by $\S 301$ of the Labor Management Relations Act. More so than other types of labor law preemption, $\$ 301$ preemption most directly controls the interaction between the emerging state individual employment rights and the federal system of collective bargaining. 
arbitration, rather than by a court. ${ }^{72}$ It has also adopted an extremely narrow standard for judicial review of the arbitration decisions. ${ }^{73}$ In practice, this means that once a claim is preempted under $\S 301$, the employee's only recourse is private arbitration. As a result, unionized workers find that, by virtue of the combination of Section 301 preemption rules and their collective bargaining agreements, they do not have access to any court to assert their state law claims.

Second, and perhaps more significantly, when a claim is preempted under $\S 301$, the state law rights are extinguished. In arbitration, the arbitrator applies the law of the collective agreement, not the external state law which the employee initially sought to invoke. ${ }^{74}$ Thus the unionized employee whose state law claim is

72 United Steelworkers of America v American Mfg. Co., 363 US 564, 567-58 (1960) (on motion to compel arbitration, judicial role limited to determining whether the plaintiff has asserted "a claim which on its face is governed by the contract"); United Steelworkers of America $v$ Warrior \& Gulf Navigation Co., 363 US 574, 582-83 (1960) (announcing presumption of arbitrability).

${ }^{73}$ United Paperworkers Int'l Union v Misco, Inc., 484 US 29, 36 (1987) ("[C]ourts are not authorized to reconsider the merits of an [arbitral] award even though the parties may allege that the award rests on errors of fact or on misinterpretation of the contract."); United Steelworkers of America v Enterprise Wheel \& Car Corp., 363 US 593, 597 (1960) (upholding arbitral award "so long as it draws its essence from the collective bargaining agreement").

In addition, employees are required to exhaust their arbitration remedies under the agreement before coming to court. Republic Steel Corp. v Maddox, 379 US 650, 652-53 (1965). And, unless the complaint includes an allegation that the union breached its duty of fair representation, finality clauses in a collective agreement preclude judicial consideration of a breach of contract claim once arbitration is completed. Hines $v$ Anchor Motor Freight, Inc., 424 US 554, 567 (1976). Even in the absence of an express finality clause, courts defer to the decision of the arbitrator. Enterprise Wheel, 363 US at 596.

74 Warrior \& Gulf, 363 US at 582. Most commentators agree that when a contract does not mention external law, an arbitrator may not base his decisions upon his understanding of the requirements of external law. The role of the arbitrator is to interpret the collective agreement, not to apply external law. See, for example, Theodore J. St. Antoine, Judicial Review of Labor Arbitration Awards: A Second Look at Enterprise Wheel and Its Progeny, 75 Mich L Rev 1137, 1140-43 (1977); Harry T. Edwards, Labor Arbitration at the Crossroads: The 'Common Law of the Shop' vs. External Law, 32 Arb J 65, 90-91 (1977); David E. Feller, The Coming End of Arbitration's Golden Age, in Barbara D. Dennis and Gerald G. Somers, eds, Proceedings of the 29th Annual Meeting of the National Academy of Arbitrators 97, 110-11 (BNA, 1976); Bernard D. Meltzer, Ruminations About Ideology, Law, and Labor Arbitration, 34 U Chi L Rev 545, 557 (1967).

To the contrary, some commentators have argued that every collective bargaining agreement should be presumed to include all applicable law, and thus the arbitrator must consider external law in order to interpret the contract. See, for example, Robert G. Howlett, The Arbitrator, the NLRB, and the Courts, in Dallas L. Jones, ed, Proceedings of the 20th Annual Meeting of the National Academy of Arbitrators 67, 83 (BNA, 1967); Dennis O. Lynch, Deferral, Waiver, and Arbitration Under the NLRA: From Status to Contract and Back Again, 44 U Miami L Rev 237, $270-71$ (1989). This position has not prevailed. 
preempted receives neither the benefit of a judicial forum nor the benefit of the substantive provisions of the state employment right.

In the sections that follow, I demonstrate that the federal courts have adopted a very broad $\S 301$ preemption doctrine.

A. The Evolution of the Section 301 Preemption Doctrine in the Supreme Court

1. The "peculiar" need for uniformity.

a) Lucas Flour (1962). Since the early 1960s, the Supreme Court has given $\S 301$ a broad preemptive scope. This trend began in 1962, in a case called Local 174 Teamsters $v$ Lucas Flour Co. ${ }^{75}$ There the Supreme Court held that when state courts decide cases involving collective bargaining agreements, they must apply the federal law of $\S 301$ rather than state contract law. ${ }^{\mathbf{7 6}}$ The Court justified this broad approach to preemption on grounds that "the subject matter of $\S 301$ (a) 'is peculiarly one that calls for uniform law." "77 In particular,

[t] he possibility that individual contract terms might have different meanings under state and federal law would inevitably exert a disruptive influence upon both the negotiation and administration of collective agreements. . . . [T] he process of negotiating an agreement would be made immeasurably more difficult by the necessity of trying to formulate contract provisions in such a way as to contain the same meaning under two or more systems of law which might someday be invoked in enforcing the contract. Once the collective bargain was made, the possibility of conflicting substantive interpretation under competing legal systems would tend to stimulate and prolong disputes as to its interpretation. ${ }^{78}$

7s 369 US 95 (1962).

28 Id at 103.

77 Id (quoting Penna. R. Co. v Public Service Comm'n, 250 US 566, 569 (1919)). A few years earlier, in Ass'n of Westinghouse Salaried Employees v Westinghouse Electric Corp., 348 US 437 (1955), the Supreme Court had remanded a $\$ 301$ case to the state court on the ground that the employees had valid state law claims, and that $\S 301$ was not intended to permit a union to sue to enforce the rights of individuals that could be enforced elsewhere. Id at 460-61. The Court so decided in order to avoid ruling on the constitutionality of $\S 301$. Id at 459-60. The Court did not address the preemption issue explicitly, but by holding as it did, the Court ruled, sub silentio, that the state law actions were not preempted.

${ }^{28}$ Lucas Flour, 369 US at 103-04. 
b) Avco (1968). Six years later, in Avco Corp. v Aero Lodge No. $735,{ }^{78}$ the Supreme Court had to determine whether $\S$ 301 preemption could provide the basis for removal jurisdiction under 28 USC $\S 1441 .^{80}$ In that case, an employer sued a union in state court for breach of a no-strike clause. The employer won, and obtained an injunction against the strike. The union tried to remove the action to a federal court in order to take advantage of the Norris-LaGuardia Act, a federal anti-injunction statute. The union argued that under Lucas Flour, § 301 preempted state breach-ofcontract actions, and that the federal courts therefore had removal jurisdiction. ${ }^{81}$

The Supreme Court agreed, granted removal, and affirmed an order dissolving the injunction that the state court had issued..$^{82}$ In doing so, it overcame its usual refusal to find removal jurisdiction in cases in which the only federal issue is raised in defense. ${ }^{83}$

79390 US 557 (1968).

so Section 1441(a) only permits removal in cases over which a federal court has original jurisdiction. 28 USC $\S 1441$ (a) (1988).

${ }^{81}$ Avco, 390 US at 558-60.

82 Id at 560 .

${ }^{83}$ Recall that $\$ 1441$ (a) only permits removal when a federal court has original jurisdiction. In turn, $\S 1331$ grants original federal jurisdiction over claims that raise a federal question. 28 USC $\S 1331$ (1988). The scope of federal question jurisdiction is determined by the well-pleaded complaint rule. See Franchise Tax Board $v$ Construction Laborers Vacation Trust, 463 US 1, 9-12 (1983). When the complaint presents no federal issue on its face, courts have disagreed as to what the well-pleaded complaint rule requires. Some hold that the rule limits the courts to a scrutiny of the complaint itself to determine the existence vel non of a federal question. Others hold that the rule requires a court to pierce the complaint and examine the underlying cause of action. See Comment, Federal Preemption, Removal Jurisdiction, and the Well-Pleaded Complaint Rule, 51 U Chi L Rev 634, 655-66 (1984). Under either approach, a federal defense is not, by itself, sufficient grounds for original federal jurisdiction or removal jurisdiction. Gully $v$ First National Bank, 299 US 109, 11213 (1936). Jurisdiction only exists if the plaintiff's case-in-chief involves federal law. A. Mark Segreti, Jr., The Federal Preemption Question-A Federal Question? An Analysis of Federal Jurisdiction Over Supremacy Clause Issues, 33 Cleve St L Rev 653, 666-67 (198485). Compare Donald L. Doernberg, There's No Reason For It; It's Just Our Policy: Why the Well-Pleaded Complaint Rule Sabotages the Purposes of Federal Question Jurisdiction, 38 Hastings L J 597, 621-26 (until 1894 federal courts found removal jurisdiction on the basis of a federal defense).

However, the issue of preemption poses a special problem for removal jurisdiction and the well-pleaded complaint rule. Preemption is normally pleaded as a defense. But when established, preemption renders the cause of action federal. See Comment, $51 \mathrm{U}$ Chi L Rev at 657-58; Comment, Artful Pleading and Removal Jurisdiction: Ferreting Out the True Nature of a Claim, 35 UCLA L Rev 315, 330-31 (1987). The Supreme Court addressed this problem in Franchise Tax Board, 463 US at 13-22, noting that, in general, the defense of preemption does not confer federal jurisdiction. 
2. Complete vs. partial preemption.

a) Franchise Tax Board (1983). Later, in a non-labor case called Franchise Tax Board $v$ Construction Laborers Vacation Trust ${ }^{84}$ the Supreme Court reaffirmed the broad preemptive scope of $\S 301$ announced in Lucas Flour and Avco. In particular, the Court explained its Avco decision:

The necessary ground of decision was that the pre-emptive force of $\S 301$ is so powerful as to displace entirely any state cause of action "for violation of contracts between an employer and a labor organization." Any such suit is purely a creature of federal law, notwithstanding the fact that state law would provide a cause of action in the absence of $\S 301 .^{\mathbf{8 5}}$

Thus Avco, as interpreted in Franchise Tax Board, said that some claims of preemption would give rise to removal jurisdiction, while others would not. Jurisdiction is appropriate when the federal interest is so powerful as to completely eclipse the state law claim. Section 301, the Court said, involved one such powerful federal interest.

The Court in Franchise Tax Board called this the "complete preemption" doctrine, "an independent corollary of the well pleaded complaint rule." ${ }^{\text {"86 }}$ Under this corollary, a claim involving interpretation or enforcement of a collective bargaining agreement is so completely a federal claim that it is converted into a $\S 301$ claim from its inception, even if alternative causes of action are pleaded in the complaint. ${ }^{87}$ The complete preemption corollary to the well-pleaded complaint rule has been applied primarily, if not exclusively, in cases raising claims preempted by $\S 301 .^{88}$ Thus the

\footnotetext{
s4 463 US 1 (1983) (refusing to find removal jurisdiction in a state attachment action where preemption was raised in defense).

${ }^{85}$ Id at 23 (footnotes omitted).

${ }^{86}$ Id at 22 .

${ }_{87}$ Id at 23-24 (citing Avco for the proposition that "if a federal cause of action completely pre-empts a state cause of action any complaint that comes within the scope of the federal cause of action necessarily 'arises under' federal law"). See Caterpillar, Inc. $v$ Williams, 482 US 386, 393-94 (1987) (discussing the application of complete preemption to $\S$ 301); Metropolitan Life Ins. Co. v Taylor, 481 US 58, 65 (1987) (noting that $\S 301$ has "extraordinary pre-emptive power"). See also Comment, $51 \mathrm{U}$ Chi L Rev at 661 (cited in note 83) ("After Franchise Tax Board, however, where federal law has 'completely preempted' the state law cause of action, it is proper to recharacterize the action as one that actually arises under federal law, despite the plaintiff's usual mastery over his complaint.").

${ }^{88}$ Metropolitan, 481 US at 63-64 ("One corollary of the well-pleaded complaint rule ... is that Congress may so completely pre-empt a particular area that any civil complaint raising this select group of claims is necessarily federal in character. For 20 years, this Court
} 
complete preemption doctrine has extended even further the preemptive reach of $\S 301$.

b) Allis-Chalmers (1985). In recent years, the Supreme Court has continued to give $\S 301$ a broad preemptive scope. In 1985, in Allis-Chalmers Corp. $v$ Lueck, ${ }^{89}$ an employee had suffered a nonoccupational injury that qualified him for disability benefits under the terms of his collective bargaining agreement. However, the employer had harassed the employee about his insurance claim and had instructed the insurer to terminate the disability payments. The employee sued the employer under a Wisconsin law that made it a tort to handle an insurance claim wrongfully and in bad faith. The lower state court found that the claim was preempted by $\S 301 .^{90}$ The Wisconsin Supreme Court disagreed. It said that the suit was not preempted by $\S 301$ because it raised a tort claim of bad faith, not a contract claim, so that the collective bargaining agreement was irrelevant. ${ }^{91}$ The defendants sought Supreme Court review.

The Supreme Court reversed, holding that the tort claim was preempted under $\S 301$. First, the Court reviewed the history of $\S 301$ preemption and reaffirmed the Lucas Flour principle: Because of the need for uniformity and predictability in the interpretation of collective bargaining agreements, $\S 301$ must be given a broad preemptive scope. ${ }^{92}$ The Court then said:

[W] hen resolution of a state-law claim is substantially dependent upon analysis of the terms of an agreement made between the parties in a labor contract, that claim must either be treated as a $\S 301$ claim, ... or dismissed as pre-empted by federal labor-contract law..$^{93}$

The Court also said that $\S 301$ would preempt such a state law claim whether it was pleaded in contract or in tort:

has singled out claims preempted by $\S 301$ of the LMRA for such special treatment." (emphasis added)). See also Adkins v General Motors Corp., 946 F2d 1201, 1207 (6th Cir 1991), cert denied, 60 USLW 3537 (May 18, 1992). ("The complete preemption corollary ... is applied primarily in cases raising claims preempted by LMRA § 301.") petition for cert filed, 60 USLW 3537 (Jan 13, 1992).

${ }^{80} 471$ US 202 (1985).

${ }^{\circ 0}$ Id at 203-06. The Wisconsin appeals court also found the claim preempted by other provisions of the federal labor law, id at $206 \& \mathrm{n} 3$, but the Wisconsin Supreme Court disagreed. Id at 207. This issue was not presented for review by the Supreme Court. Id at 208.

91 Id at 207.

92 Id at 209-11.

${ }^{93}$ Id at 220 (citation omitted). 
[Q] uestions relating to what the parties to a labor agreement agreed, and what legal consequences were intended to flow from breaches of that agreement, must be resolved by reference to uniform federal law, whether such questions arise in the context of a suit for breach of contract or in a suit alleging liability in tort. Any other result would elevate form over substance and allow parties to evade the requirements of $\S 301$ by relabeling their contract claims as claims for tortious breach of contract. ${ }^{84}$

Applying this doctrine to the facts before it, the Court reasoned that the collective agreement could contain implied terms defining the employer's duty to pay insurance benefits. It concluded that "[t] $\mathrm{t}$ he duties imposed and rights established through the state tort thus derive[d] from the rights and obligations established by the contract." 95

In addition, the Court found that the state tort alleged was "derived from the implied covenant of good faith and fair dealing found in every contract."96 Because the state law right that the plaintiff asserted "not only derive[d] from the contract, but [wa]s defined by the contractual obligation of good faith, any attempt to assess liability here inevitably [would] involve contract interpretation."97 Thus the Court held that the claim should have been dismissed, either for failure to exhaust the contractual arbitration procedure (if the plaintiff's complaint were interpreted, or amended, to assert a claim under $\S 301$ ), or as preempted under $\S 301$ (if the plaintiff had forgone his federal claim)..$^{98}$

c) Caterpillar (1987). Two years later, however, in Caterpillar Inc. $v$ Williams, the Supreme Court held that an employee's claim for breach of an individual employment contract was not completely preempted by $\S 301 . .^{99}$ In that case, employees claimed that their employer had breached a contract they had signed before they were in the bargaining unit or covered by the collective

94 Id at 211.

os Id at 217.

${ }_{96}$ Id.

97 Id at 218 .

9s Id at 220-21 (citing Maddox, 379 US at 652). On the disposition of cases in which a state court finds federal preemption, see Comment, 35 UCLA L Rev at 353 \& $n 181$ (cited in note 83 ).

99 482 US 386, 396-97 (1987). The Court said, in dicta, that the defendant could raise, as a defense in state court, that plaintiff's action was preempted by other provisions of the NLRA. Id at 397-98. 
bargaining agreement. They brought their claims in state court. The employer attempted to create a federal issue by arguing in defense that the collective bargaining agreement included a waiver of any pre-existing individual contractual rights. ${ }^{100}$ On this basis, the employer removed the action to federal court and moved to have it dismissed, as a $\S 301$ action, for failure to exhaust contractual remedies.

The federal district court found removal jurisdiction and dismissed. The Ninth Circuit, however, reversed, finding that the complaint did not arise under $\S 301$, so that the federal courts did not have removal jurisdiction. ${ }^{101}$ The Supreme Court affirmed. While acknowledging the broad preemptive scope of $\S 301$, the Court refused to find preemption because the employees' complaint had not relied upon the collective bargaining agreement. Further, the Court found that the individual contractual rights upon which they had relied did not depend on an interpretation of the collective agreement. ${ }^{102}$ The Court also rejected the employer's effort to "inject[] a federal question into an action that asserts what is plainly a state-law claim, transform the action into one arising under federal law, [and] thereby select[] the forum in which the claim shall be litigated."103

Unfortunately, the Court did not explain why the employer's argument in Caterpillar that the collective agreement limited the employer's obligation to the plaintiff was a mere defense, while in Allis-Chalmers, the employer's argument that the collective agreement limited or qualified its obligation to pay medical insurance preempted the plaintiff's claim. The opinions in Allis-Chalmers and Caterpillar thus created uncertainty as to whether $\S 301$ preempted state law claims by employees to which the employer argued in defense that the case was dependent upon an implied term or waiver in a collective bargaining agreement. This type of preemption issue regularly arises when a unionized employee brings a state law wrongful discharge claim.

Some judges attempted to reconcile Caterpillar and AllisChalmers by interpreting Caterpillar as addressing only a question of $\S 1441$ removal jurisdiction, not the substantive issue of preemp-

\footnotetext{
100 Id at $388-90$.

101 Id at $390-91$.

102 Id at 395.

103 Id.
} 
tion under $\S 301 .^{104}$ That is, they reasoned that the complete preemption doctrine does not mean that all cases that are preempted under $\S 301$ give rise to removal jurisdiction. Under this view, Caterpillar does not alter the standard for determining when an employer's defense creates removal jurisdiction, but it does mean that there is a stricter standard for asserting removal jurisdiction under $\S 1441$ than for finding substantive preemption under $\S 301$. Thus one court spoke of "the possibility that the Caterpillar plaintiffs' claims were partially preempted."10s

The partial preemption theory has a serious flaw: How could a federal court not have removal jurisdiction over a claim that is completely preempted by $\S 301$ ? If complete preemption means what it says-that $\S 301$ displaces all state causes of action and converts an otherwise ordinary state law action into a $\S 301$ action from its inception ${ }^{\mathbf{1 0 8}}$ - then the claim must involve a federal question, and removal jurisdiction must exist.

Most courts and commentators have rejected the partial preemption interpretation of Caterpillar. Instead, they view Caterpillar as limiting both substantive preemption under $\S 301$ and removal jurisdiction under $\S 1441$ in cases in which the employer raises a defense based on the collective bargaining agreement. ${ }^{107}$ Indeed, the only circuit that has specifically embraced the partial preemption interpretation of Caterpillar-the Sixth Circuit in Adkins-noted that the claims which were preempted, but did not give rise to removal jurisdiction, were preempted by other provisions of the labor law, not by $\S 301 .{ }^{108}$

In other words, the tension between Allis-Chalmers's broader $\S 301$ preemption and Caterpillar's narrower approach cannot so easily be resolved. However, the Court subsequently has indicated

104 See, for example, Adkins, 946 F2d at 1207-08 (interpreting Caterpillar as a case of partial exemption); Schacht $v$ Caterpillar, Inc., 213 Ill App 3d 169, 571 NE2d 1215, 1217 (1991) (noting that "the issue in [Caterpillar] was removal jurisdiction, not the substantive merits of a pre-emption defense."), cert denied, 112 S Ct 1306 (1992). See also Richard E. Schwartz and James E. Parrot, A New Look at Federal Labor Law Preemption: Unionized Employees' Claims in State Court, 7 St Louis U Pub L Rev 297, 305 (1988) (noting the difficulty in reconciling Allis-Chalmers and Caterpillar).

${ }^{105}$ Adkins, 946 F2d at 1208.

106 Caterpillar, 482 US at 393.

${ }^{107}$ See, for example, McCormick v AT\&T Technologies, Inc., 934 F2d 531, 534 (4th Cir 1991) (en banc), cert denied, $112 \mathrm{~S} \mathrm{Ct} 912$ (1992) (standard for $\$ 301$ preemption same as standard for removal jurisdiction). Accord Berda $v$ CBS, Inc., 881 F2d 20, 23-24, 26 (3d Cir 1989). See also Schwartz and Parrot, 7 St Louis U Pub L Rev at 305 (cited in note 104) ("[Caterpillar] made it clear that defensive federalization of a claim is no longer permitted.").

108 Adkins, 946 F2d at 1208. 
that it favors the broader preemptive scope that Allis-Chalmers exemplified.

3. Recent decisions broadening the scope of preemption.

a) Hechler (1987). In 1987, the Supreme Court decided a case that posed the question of whether an employee's tort claim against her union was preempted under $\S 301$. In International Brotherhood of Electrical Workers $v$ Hechler, an injured employee sued her union in state court for breaching its implied duty to ensure its members a safe workplace. ${ }^{109}$ The Supreme Court found the claim preempted because it was not "sufficiently independent of the collective-bargaining agreement to withstand the pre-emptive force of $\S 301$." 110 The Court reasoned that, under Florida law, a union had no independent duty to provide a safe workplace; the union only could have assumed such a duty under a collective bargaining agreement. Thus to decide liability, the court would have to interpret the collective agreement to determine whether the union undertook such a duty. ${ }^{111}$ In short, this decision, like AllisChalmers, affirmed the broad preemptive scope of $\S 301$.

b) Lingle (1988). In 1988, the Supreme Court again addressed the question of the scope of $\S 301$ preemption. In Lingle $v$ Norge Division of Magic Chef, an employee had brought a state law tort claim against her employer, alleging that she had been fired in retaliation for filing a workers' compensation claim. ${ }^{112}$ The lower court had found that the claim was preempted, because the employee had been covered by a collective bargaining agreement, and because the facts underlying the tort of retaliatory discharge would have been the same as for a grievance under the just cause provision of the collective bargaining agreement. ${ }^{113}$

The Supreme Court reversed. It rejected the argument that factual parallelism between a state claim and a grievance automatically renders the state law claim preempted. Rather, "as long as the state-law claim can be resolved without interpreting the agreement itself, the claim is 'independent' of the agreement for $\S 301$

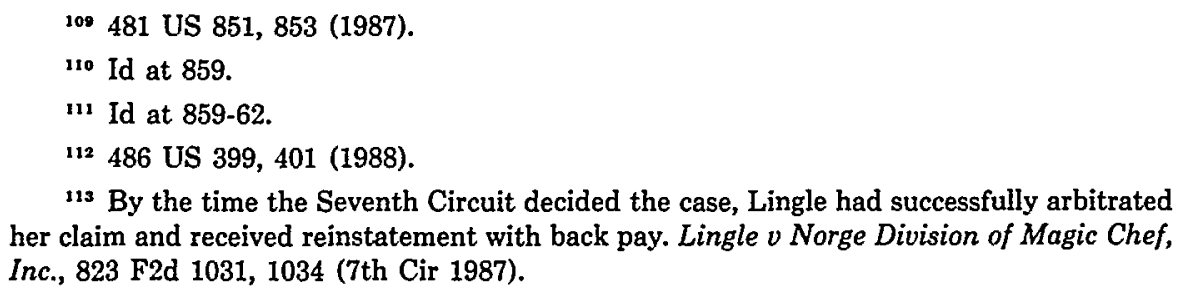

113 By the time the Seventh Circuit decided the case, Lingle had successfully arbitrated her claim and received reinstatement with back pay. Lingle $v$ Norge Division of Magic Chef, Inc., 823 F2d 1031, 1034 (7th Cir 1987). 
pre-emption purposes."114 The Court concluded: "[A]n application of state law is pre-empted by $\S 301 \ldots$ only if such application requires the interpretation of a collective bargaining agreement."115 The Court held that the state court could resolve the retaliation claim without reference to the collective agreement, so there was no $\S 301$ preemption.

While the Court in Lingle did not preempt the claim of retaliatory discharge, the case did not directly address the question of whether $\S 301$ would preempt a state law claim to which an employer interposed a contractual defense. However, one commentator has noted that the language of Lingle is a subtle but important departure from Allis-Chalmers, which said that only claims that were "substantially dependent" on the collective agreement were preempted. ${ }^{116}$ She argues that the above-quoted language of Lingle suggests that if a court must interpret a collective agreement to resolve any aspect of a case-the plaintiff's case-in-chief or the defense-then the plaintiff's claim is preempted.117 Indeed, she suggests that, after Lingle, employers need only assert a colorable contractual defense in order to supplant the state court's jurisdiction. ${ }^{118}$ If she is right, then the Lingle test will result in more preemption than did either Allis-Chalmers or Caterpillar. ${ }^{119}$

in Lingle, 486 US at 410.

115 Id at 413.

116 Note, The Need for a New Approach to Federal Preemption of Union Members' State Law Claims, 99 Yale L J 209 (1989). The Eighth Circuit adopted this interpretation of Lingle in Hanks $v$ General Motors Corp., 859 F2d 67, 70 (8th Cir 1988):

Lingle makes plain ... that the defenses as well as the claims, must be considered in determining whether resolution of the state law claims requires construing the collective bargaining agreement. The factual background of the entire case must be examined against an analysis of the state tort claim and a determination made whether the provisions of the collective bargaining agreement come into play.

But see Newberry $v$ Pacific Racing Ass'n, 854 F2d 1142, 1146-47 (9th Cir 1988) (finding no distinction between the Lingle and the Allis-Chalmers tests).

117 Note, 99 Yale L J at 210 (cited in note 116). Footnote 12 in Lingle said that not every claim "tangentially involving a provision of a collective-bargaining agreement is preempted." 486 US at $413 \mathrm{n} 12$ (quoting Allis-Chalmers, 471 US at 211). The Court gave as a hypothetical example a state law claim that necessitated a look at the collective agreement to determine the back pay to which the claimant was entitled. Id. The Court said that the need to consult the agreement to determine back pay would not, standing alone, preempt the claim. Id. The extreme narrowness of this exception lends support to the argument that Lingle gave a broader scope to $\S 301$ preemption than did Allis-Chalmers.

118 Note, 99 Yale L J at 209-11 (cited in note 116).

119 Id at 209. See also Labor Arbitration and the Law of Collective Bargaining, 7 Labor Law 747, 755-61 (1991) (during 1990, after Lingle, the trend was toward more preemption under § 301). But see Note, Labor Law Preemption Under Section 301: New Rules for an Old Game, 40 Syracuse L Rev 1279, 1291-93 (1989) (arguing that the Lingle test limited the preemptive scope of the Allis-Chalmers test). See also Note, Federal Labor Law Preemp- 


\section{B. A Topology of the Section 301 Doctrine in the Lower Federal Courts}

Whether or not Lingle has brought about more instances of $\S 301$ preemption, it certainly has not simplified the preemption doctrine. Just last year, the Ninth Circuit termed $\S 301$ preemption a "thicket," a "tangled and confusing interplay between federal and state law,"120 and "one of the most confused areas of federal court litigation."121 However, despite this apparent confusion, lower federal courts have shown a strong tendency, both before and after Lingle, to find unionized workers' state law claims preempted. ${ }^{122}$

There are two distinct methods of reasoning that courts employ in deciding $\S 301$ preemption cases, both of which are heavily tilted in favor of preemption. One method is to find preemption on the basis of a contract-interpretation issue raised by the employer in defense. Often such defenses are based on general contract provisions to which the employer urges an expansive interpretation. For example, one court has found a contractual provision granting an employer the right to make "reasonable rules and regulations from time to time" sufficient to preempt an employee's right to be free of drug testing under state law. ${ }^{123}$ Other courts have found

tion of State Wrongful Discharge Claims, 58 U Cin L Rev 491, 526-27 (1989) (arguing that Lingle opened the door to union workers' state law suits).

${ }^{120}$ Galvez v Kuhn, 933 F2d 773, 774 (9th Cir 1991).

${ }^{121}$ Id at 776 (quoting Note, 99 Yale $\mathrm{L} J$ at 209 (cited in note 116)). See also Singh v Lunalilo, 6 IER Cases (BNA) 1682, 1684 (D Hawaii 1991) (on difficulty of reconciling the "dozens, if not hundreds, of federal cases addressing the issue of the scope of section 301 pre-emption on [sic] state law claims.").

${ }^{122}$ See notes 128-35 and accompanying text. See also Note, $58 \mathrm{U}$ Cin L Rev at 555 (cited in note 119) (arguing that all wrongful discharge claims of unionized workers are preempted by $\S 301$ ). But see Jane Byeff Korn, Collective Rights and Individual Remedies: Rebalancing the Balance After Lingle, 41 Hastings L J 1149, 1167 (1990) (arguing that, after Lingle, most employee claims based on state tort laws are not preempted).

Professor Korn concludes that Lingle opened the door for unionized employees to bypass their grievance procedures and bring a host of lawsuits in the state courts. 41 Hastings $\mathrm{L} J$ at 1165 . My research reaches the opposite conclusion. Indeed, I believe that her research does too. Of the twenty-six cases cited by Korn in notes 53, 85, and 108 as the basis for her claim, twelve were cases involving retaliation for filing of workers' compensation claims, the precise issue decided by the Supreme Court in Lingle. In those cases, it is not at all surprising that the lower courts followed the Supreme Court's ruling in Lingle. Of the remaining fourteen cases Professor Korn cites, twelve were cases in which the state law claims were preempted by federal law, so that the unionized worker could not maintain the state court action. Thus, if one exempts the Lingle fact-pattern, only two of Professor Korn's twentysix cases cited were cases in which the unionized worker was permitted to sue in state court.

${ }^{123}$ Jackson v Liquid Carbonic Corp., 863 F2d 111, 113-15 (1st Cir 1988) (employee's claim preempted by the collective bargaining agreement, which contained a standard management rights clause giving the company the "right to post reasonable rules and regulations 
preemption on the basis of implied contract clauses or novel readings of explicit ones. ${ }^{124}$

The other method is to find preemption by interpretation of state law. By this method, a court first looks to see whether an asserted state law employment right is waivable under state law. ${ }^{125}$ If it is, then theoretically the court should look to see if the employee in fact waived the right in a clause of the collective bargaining agreement. However, this exercise requires the court to interpret the collective agreement, something which courts are extremely reluctant to do. ${ }^{126}$ Instead they preempt the claim because to decide whether the state law claim was actually waived, the court would have to interpret the collective bargaining agreement. Hence, by this method, a state employment right that is waivable is automatically preempted. ${ }^{127}$

A survey of recent preemption cases reveals a very broad tendency for courts to preempt unionized workers' state law claims. Indeed, with very few exceptions, courts always preempt unionized workers' attempts to assert state law employment rights. The

from time to time"). See also Utility Workers of America $v$ Southern California Edison Co., 852 F2d 1083, 1086 (9th Cir 1988) (constitutional claims preempted by contractual language that granted the company the right to manage the plant, direct the work force, and implement safety rules); Schlacter-Jones v General Telephone, 936 F2d 435, 439 (9th Cir 1991) (employee's claims preempted because they were "inextricably intertwined" with analysis of the collective bargaining agreement, which governed working conditions at the company).

${ }^{124}$ See, for example, McCormick, 934 F2d at 536 (holding that plaintiff's claim against an employer involved "implied rights and duties" in the collective bargaining agreement, and thus the claims required interpretation of the agreement and were preempted); Jones $v$ General Motors Corp., 939 F2d 380, 383 (6th Cir 1991) (\$ 301 preemption not limited to cases where the precise meaning of words in the collective bargaining agreement is the crux of the state-based claim); Laws v Calmat, 852 F2d 430 (9th Cir 1988) (drug testing claims preempted on the basis of implied terms).

${ }^{125}$ For example, in Lingle, the Supreme Court found that the Illinois state-law right not to be fired for filing a workers' compensation claim was not waivable. 486 US at 409 \& n 9. Thus it found that the collective bargaining agreement could not have modified the state law right. Id. See also Local No. 57, United Ass'n of Journeymen \& Apprentices of Plumbing $v$ Bechtel Power Corp., 834 F2d 884, 889-90 (10th Cir 1987) (no preemption because anti-blacklisting provisions of Utah Constitution not waivable); Tellez $v$ Pacific Gas and Electric, 817 F2d 536, 538 (9th Cir 1987) (no preemption because state right not negotiable).

${ }^{128}$ See Warrior \& Gulf, 363 US at 582 (arbitrators, not courts, should interpret collective bargaining agreements).

${ }^{122}$ See, for example, Hyles $v$ Mensing, 849 F2d 1213, 1216-17 (9th Cir 1988) (preempting claims of emotional distress and defamation because they did not involve nonnegotiable state right); Laws, 852 F2d at 433 \& n 4; Utility Workers, 852 F2d at 1086 (right to be free of drug testing, located in California's state constitution's privacy guarantee, can be waived). See also Angel Gomez III, Preemption and Preclusion of Employee Common Law Rights by Federal and State Statutes, 11 Indus Rel L J 45, 51 n 42 (1989) (discussing the waiver issue in Utility Workers and Laws). 
broad trend, as well as the narrow exceptions, are apparent when we break the cases down into categories.

\section{Claims that usually are preempted.}

A great many of the developments in state employment law have been in the area of wrongful discharge. Unionized workers have been particularly disadvantaged in this area by the preemption rules. ${ }^{128}$ In general, the following types of claims by employees against employers are almost always preempted:

1. unjust dismissal claims alleging breach of an implied covenant of good faith and fair dealing; ${ }^{129}$

2. unjust dismissal claims alleging a tort of wrongful discharge, ${ }^{130}$

3. unlawful drug testing claims; ${ }^{131}$

4. claims that the employer breached a promise to an employee who was a member of a bargaining unit; ${ }^{132}$

128 Anthony Herman, Wrongful Discharge Actions after Leuck and Metropolitan Life Insurance: The Erosion of Individual Rights and Collective Strength?, 9 Indus Rel L J 596, 639-40 (1987). See also Daniel N. Kosanovich, Inching Through the Maze: Recent Developments in Preemption Under the NLRA and the Impact of Caterpillar, Hechler, and Others, 4 Labor Law 225, 253-54 (1988) (claims involving tort of wrongful discharge or contract breach routinely preempted).

129 See, for example, Bloom v Universal City Studios, 734 F Supp 1553, 1560 (C D Cal 1990), aff'd without opinion, 933 F2d 1013 (9th Cir 1991); Fox v Parker Hannifin Corp., 914 F2d 795, 801 (6th Cir 1990); Cook v Lindsay Olive Growers, 911 F2d 233, 238-39 (9th Cir 1990); Newberry v Pacific Racing Ass'n, 854 F2d 1142, 1147 (9th Cir 1988); Paige v Henry J. Kaiser Co., 826 F2d 857, 866 (9th Cir 1987); Harper v San Diego Transit Corp., 764 F2d 663, 668-69 (9th Cir 1985); Taylor v St. Regis Paper Co., 560 F Supp 546, 549 (C D Cal 1983).

${ }_{130}$ See, for example, Singh, 6 IER Cases (BNA) at 1682, 1686-87; Cook, 911 F2d at 237-38; Hanks v General Motors Corp., 859 F2d 67, 69 (8th Cir 1988); Kirby v Allegheny Beverage Corp., 811 F2d 253, 256 (4th Cir 1987); Desoto v Yellow Freight Systems, Inc., 811 F2d 1333, 1135-36 (9th Cir 1987); Durrette v UGI Corp., 674 F Supp 1139, 1143 (M D Pa 1987); Crocker v Synpol, Inc., 732 SW2d 429, 432-33 (Tex App 1987); Nelson v OwensCorning Fiberglas Corp., 648 F Supp 44, 47 (D Mont 1986); Hohn v Kaiser Cement Corp., 624 F Supp 549, 551-52 (D Mont 1986); Evangelista $v$ Inlandboatmen's Union of the Pacific, 777 F2d 1390, 1400-01 (9th Cir 1985); Mitchell v Pepsi-Cola Bottlers Inc., 772 F2d 342, 344-45 (7th Cir 1985); Faust v RCA Corp., 612 F Supp 540, 542 (M D Pa 1985); Taylor, 560 F Supp at 549 .

131 See, for example, Schlacter-Jones, 936 F2d at 440-42; Jackson, 863 F2d at 118-20; Utility Workers, 852 F2d at 1086-87; Laws, 852 F2d at 432-33; Strachan v Union Oil Co., 768 F2d 703, 705 (5th Cir 1985).

${ }^{132}$ The claims are preempted whether the plaintiff pleads the breach of promise as a breach of contract, misrepresentation, promissory fraud, or promissory estoppel. See, for example, Dougherty v AT\&T, 902 F2d 201, 204 (2d Cir 1990) (promise of job security); Fox, 914 F2d at 801-02 (promise to investigate harassment by co-workers); Ulrich $v$ Goodyear Tire and Rubber Co., 884 F2d 936, 938 (6th Cir 1989) (promise of right to reenter bargaining unit after transferring to supervisory position); Terwilleger $v$ Greyhound Lines, Inc., 882 
5. claims of defamation for an employer's derogatory remarks about an employee made to co-workers; ${ }^{133}$

6. claims that an employer conducted an unlawful search of a person or automobile; ${ }^{134}$

7. claims concerning the mishandling of health insurance, medical leave, or other medical obligations. ${ }^{135}$

\section{Claims that usually are not preempted.}

On the other hand, there are a few types of claims by employees against employers which the courts almost never preempt:

1. claims of retaliatory discharge for filing a workers' compensation claim; ${ }^{138}$

F2d 1033, 1037-38 (6th Cir 1989) (promise of job security); Bache v AT\&T, 840 F2d 283, 285-86 \& n 1 (5th Cir 1988) (promise of job security at new position if employee agreed to transfer from bargaining unit); Maushund v Earl C. Smith, Inc., 795 F2d 589, 589-90 (6th Cir 1986) (promise of job security); Mason v Continental Group, Inc., 763 F2d 1219, 1222-24 (11th Cir 1985) (promise to keep plant open); Eitmann v New Orleans Public Service, Inc., 730 F2d 359, 362-63 (5th Cir 1984) (promise of full compensation during period of disability). See also Schacht, 571 NE2d at 1218 (individual written apprenticeship contracts). But see Wells v General Motors, 881 F2d 166, $172-75$ (5th Cir 1989) (no preemption of fraud and misrepresentation claims regarding promise that laid-off employees would be eligible for reemployment).

${ }^{133}$ See, for example, Strachan, 768 F2d at 706 (state law defamation claims are preempted unless plaintiff shows malice); Mitchell, 772 F2d at 348 \& n 20. But see Meier $v$ Hamilton Standard Electronic Systems, Inc., 748 F Supp 296, 299-300 (E D Pa 1990) (defamatory statements not preempted if made to individuals outside the scope of the agreement); Tellez, 817 F2d at 538 (holding that the agreement does not govern defamatory statements), in which the courts refused to preempt defamation claims.

${ }_{134}$ See, for example, Romero v Hilton Hotels Corp., 137 Labor Rel Ref Man (BNA) 2647, 2649-50 (D Hawaii 1991) (search of person); Stikes v Cheuron USA, Inc., 914 F2d 1265, 1269-70 (9th Cir 1990), cert denied, $111 \mathrm{~S} \mathrm{Ct} 2015$ (1991) (search of automobile); Kirby, $811 \mathrm{~F} 2 \mathrm{~d}$ at 256 (search of person and automobile).

${ }^{138}$ See, for example, Perugini v Safeway Stores, 935 F2d 1083, 1088 (9th Cir 1991) (preempting claims growing out of employer's refusal to give employee light duty during pregnancy and instead forcing her to take medical leave); Terwilliger, 882 F2d at 1037-38 (preempting right to reemployment after medical disqualification because created by contract, not state law); Brinkman v State, 224 Mont 238, 729 P2d 1301, 1308-09 (1989) (preempting wrongful discharge claim arising from termination for failing to provide proper request for medical leave).

${ }^{136}$ Since Lingle, courts have uniformly refused to preempt claims alleging retaliation for filing workers' compensation claims. See, for example, Krashna v Oliver Realty, Inc., 895 F2d 111, 115 (3d Cir 1990) (distinguishing plaintiff's termination from ordinary wrongful discharge claim because the complaint involved a course of illegal conduct that preceded the discharge and because the plaintiff expressly alleged wrongs separate from the collective bargaining agreement); McEwen v Delta Air Lines, Inc., 919 F2d 58, 59 (7th Cir 1990) (not discussing preemption, but applying Illinois law); Eldridge $v$ Felec Services, Inc., 920 F2d 1434, 1438-39 (9th Cir 1990) (holding that state law requires only a determination whether the workers' compensation claim was the primary cause of discharge, an injury that requires 
2. claims that the employer breached a promise made to an employee before the employee entered the bargaining unit; ${ }^{137}$

3. claims of discrimination on the basis of race, age, gender, or some other protected classification. ${ }^{138}$

What is interesting about these three categories of non-preempted claims is that they all parallel specific Supreme Court deci-

no interpretation of the collective-bargaining agreement); Smolarek v Chrysler Corp., 858 F2d 1165, 1168-69 (6th Cir 1988) (same). But see Magerer v John Sexton \& Co., 912 F2d 525, 529-30 (1st Cir 1990) (preempting workers' compensation retaliation claim because state statute exempts workers covered by collective bargaining agreements).

Prior to Lingle, the courts were divided on this issue. For retaliation claims that were not preempted, see, for example, Baldracchi v Pratt \& Whitney Aircraft Division, 814 F2d 102, 105 (2d Cir 1987) (retaliation claim independent of agreement); Bonner v Fleming Companies, Inc., 734 SW2d 764, 766 (Tex App 1987) (same); Sutton v Southwest Forest Industries, Inc., 628 F Supp 1034, 1036 (D Kan 1985) (state policy of protecting workers from retaliatory discharge for filing workers' compensation claims does not conflict with the federal interest in protecting the collective-bargaining process); Midgett $v$ Sackett-Chicago, Inc., 105 Ill 2d 143, 473 NE2d 1280, 1283 (1984) ("[I]n order to provide a complete remedy it is necessary that the victim of a retaliatory discharge be given a remedy in tort, independent of any contract remedy the employee may have based in the collective-bargaining agreement."). For retaliation claims that were preempted, see, for example, Richard v Portland General Electric, 83 Or App 59, 730 P2d 578, 579 (1986)(citing state and federal policy of exclusivity of collective bargaining remedies); Johnson v Hussmann Corp., 610 F Supp 757, 759 (E D Mo 1985) (because the state tort law directly affects the agreement, it is preempted); Schuyler v Metropolitan Transit Co., 374 NW2d 453, 455-56 (Minn App 1985) (failure to exhaust grievances under federal law precluded suit for retaliatory discharge under state law); Mouser v Granite City Steel Division of National Steel Corp., 121 Ill App 3d 834, 460 NE2d 115, 118 (5th Dist 1984) (employee cannot sue in tort separate from collective bargaining agreement).

${ }^{137}$ See, for example, Berda v CBS, Inc., 881 F2d 20, 25-27 (3d Cir 1989) (pre-hire promise of job security); Anderson v Ford Motor Co., 803 F2d 953, 958 \& n 7 (8th Cir 1986) (promise that newly-hired employees would not be bumped by employees on preferential hiring list); Varnum v Nu-Car Carriers, Inc., 804 F2d 638, 640 (11th Cir 1986) (pre-hire promises about potential income and job assignments). But see Bales $v$ General Telephone Co., 795 F2d 775, 779-80 (9th Cir 1986) (preempting suit to enforce pre-hire promises about future benefits and job security). Angel Gomez has stated that the circuits are split over whether to preempt claims involving pre-hire contracts. However, he refers only to Bales as a case of preemption. Gomez, 11 Indus Rel $L J$ at 52 \& n 48 (cited in note 127).

${ }^{138}$ See, for example, Cook, 911 F2d at 238 (religious discrimination); Smolarek, 879 F2d at 1332-33 (handicap discrimination); Ackerman v Western Electric Co., 860 F2d 1514, 1517-18 (9th Cir 1988) (handicap discrimination); Nelson, $648 \mathrm{~F}$ Supp at 47 (sex discrimination); Austin v New England Telephone, 644 F Supp 763, 767 (D Mass 1986) (handicap discrimination); Scott v New United Motor Mfg., Inc., 632 F Supp 891, 894-95 (N D Cal 1986) (race discrimination); Peoples v Pennsylvania Power and Light Co., $638 \mathrm{~F}$ Supp 402, 408 (M D Pa 1985) (race discrimination). See also Carrington v RCA Global Communications, 762 F Supp 632, 641 (D NJ 1991) ("Following Lingle, courts have uniformly held that state anti-discrimination laws are not preempted by $\S 301$ of the LMRA . . . even where the labor contract itself prohibits discrimination."). But see Laczay $v$ Ross Adhesives, 855 F2d 351,352 (6th Cir 1988) (describing district court action preempting allegation of violation of Michigan Age Discrimination statute and denying right to appeal). 
sions. For example, claims for workers' compensation retaliation involve the same issue as did Lingle, in which the Court did not preempt the claim. Similarily, the claims for breach of pre-employment promises replicate the fact pattern in Caterpillar, which also found no preemption. And the discrimination claims pose a similar issue to that in Alexander $v$ Gardner-Denver Co., another case in which the Court did not defer to the contractual arbitration machinery. ${ }^{139}$ Indeed, the Supreme Court in Lingle expressly endorsed an exception to $\S 301$ preemption for claims under state anti-discrimination laws. ${ }^{140}$ Thus all three categories are narrow exceptions to an otherwise broad preemption doctrine. ${ }^{141}$

There is one additional category of claims that are not preempted: claims not cognizable under a union's grievance procedure. Thus, for example, claims against persons who are not parties to a collective agreement, or who are not subject to the grievance and arbitration procedures, are rarely preempted..$^{142}$ Similarily, cases brought by persons who do not have access to the grievance procedure rarely are preempted. ${ }^{143}$ In addition, claims

139. 415 US 36 (1974). There the Supreme Court held that an employee can maintain a race discrimination action under the civil rights acts, even if she had previously arbitrated the same issue. That is, the federal courts need not defer to the decision of the arbitrator in matters involving discrimination. Id at 59-60. Deferral questions are similar but not identical to $\S 301$ preemption questions. Section 301 preemption resolves the tension between collectively-bargained rights and state-created individual employment rights. Deferral resolves the tension between collectively-bargained rights and federally-created individual employment rights. Section 301 preemption is derived from the Supremacy Clause and thus is constitutionally compelled. Deferral is derived from the federal courts' authority to reconcile and harmonize two conflicting federal statutes; it may reflect prudent judicial policy, but it is not constitutionally compelled.

When an individual maintains a claim under state fair employment laws, the issue is preemption rather than deferral, but the courts reach the same conclusion as in GardnerDenver. That is, a union's grievance procedure does not preempt a claim for discrimination based on state law. Id at 51-52. One commentator has suggested that courts should use the reasoning of Gardner-Denver to decide all issues of $\S 301$ preemption, not merely those involving discrimination. Herman, 9 Indus Rel $L J$ at 615-16 (cited in note 128).

140486 US at $412-13$.

${ }^{141}$ See Singh, 6 IER Cases (BNA) at 1686 (noting exceptions to $\$ 301$ preemption for claims alleging workers' compensation retaliation and employment discrimination).

${ }^{142}$ See, for example, Meier, 748 F Supp at 300-01 (defamatory statements made by employer to persons not employed by company and not involved in investigation of employee); Dougherty v Parsec, Inc., 872 F2d 766, 770-71 (6th Cir 1989) (tortious interference claim against client of plaintiff's employer who allegedly requested plaintiff's dismissal in retaliation for filing an OSHA complaint, even though the employee attempted to use the grievance procedure to protest the firing).

${ }^{143}$ See, for example, White $v$ National Steel Corp., 938 F2d 474, 484 (4th Cir 1991) (no preemption because plaintiffs were not represented by union and had no access to grievance procedure); Scott v New United Motor Manufacturing, Inc., 632 F Supp 891, 893-94 (N D Cal 1986) (no preemption of fraud and IIED claims because plaintiff was a probationary 
arising after the expiration of the collective bargaining agreement are not preempted.144 There, too, courts reason that if no grievance and arbitration procedure is available to remedy the issue, they should not preempt.

This last exception to the otherwise broad tendency to preempt indicates the central role that union grievance and arbitration procedures play in the courts' determination of whether or not to preempt. ${ }^{145}$ Ostensibly this factor should be irrelevant because, under Allis-Chalmers and Lingle, it is the relationship between the state law claim and the collective bargaining agreement that should decide the preemption question, not the relationship between the state law claim and the means to enforce the collective agreement. In Section IV below, I explore the logic that links the contractual enforcement procedure and the decision by a court to preempt.

3. Claims that sometimes are preempted and sometimes are not.

There are also a few categories of $\S 301$ preemption claims that go both ways:

employee and, under the applicable collective agreement, was not entitled to file a grievance). See also Caterpillar, 482 US at 395 \& $n 9$ (no preemption for claims of employees not covered by collective bargaining agreement). But see Young v Anthony's Fish Grottos, Inc., 830 F2d 993, 1000 \& n 3 (9th Cir 1987) (preempting probationary employee's claim of wrongful discharge even though employee was not covered by the job security terms of the collective agreement, because the employee had access to the grievance procedure).

Professor William Gould IV critizes the Scott decision as inconsistent with The Steelworkers Trilogy (see note 200) and the "virtues of industrial self-government." Gould, 9 Indus Rel L J at 11-12 (cited in note 71).

${ }^{144}$ See, for example, Overby $v$ Cheuron, USA, 132 Labor Rel Ref Man (BNA) 2334, 2337 (9th Cir 1989) (for $\$ 301$ purposes, the agreement ceases to exist when it expires, so there can be no preemption).

${ }^{145}$ National Steel, 938 F2d at 481 (The driving force behind the Supreme Court's decision in Lueck was "not only the need for uniformity of interpretation that was identified in Lucas Flour, but the need to preserve the central role of arbitration established in collective bargaining contracts."); McCormick, 934 F2d at 538 ("There are few workplace quarrels that could not be framed as some form of tortious conduct. Our holding that [the plaintiff's] state law claims are preempted by $\S 301$ protects the continued vitality of grievance procedures as a fair and efficient means for the resolution of labor disputes, and it also furthers the uniformity concerns underlying § 301."); Beatrice Foods, 921 F2d at 1020 ("[T] he holdings in Allis-Chalmers and Bechtel Power are consistent with the "Steelworkers Trilogy" [in which the Supreme Court] stated a broad policy favoring arbitration under collective bargaining agreements."); Marine Transport Lines $v$ Int'l Organization of Masters, 609 F Supp 282, 287 (S D NY 1985) ("It was precisely the need to maintain the effectiveness of arbitration that prompted the Court in Lueck to find that a derivative tort claim was preempted by federal law under Section 301 where the collective bargaining agreement imposed the same rights and obligations as would the derivative tort."). 
1. claims concerning issues that were not addressed by the collective agreement, and thus cannot be brought in arbitration; ${ }^{146}$

2. claims for intentional infliction of emotional distress ("IIED"), due to outrageous conduct by the employer; ${ }^{147}$

${ }^{1 * 6}$ Cases not preempting these claims include Meier $v$ Hamilton Standard Electronic Systems, Inc., 748 F Supp 296 (E D Pa 1990), in which a plaintiff alleged that his employer falsely accused him of drug trafficking, and fired him. The plaintiff prevailed in arbitration and was reinstated. Id at $298 \mathrm{n} 1$. Thereafter, he sued for defamation, intentional infliction of emotional distress, invasion of privacy, and various other torts. The district court refused to preempt the defamation, intentional infliction of emotional distress ("IIED"), and privacy claims because the grievance procedure under the union contract could not redress such wrongs. Id at 300 . See also Fox, 914 F2d at 802 (no preemption for claims of emotional distress because unrelated to collective bargaining agreement); Wells, 881 F2d at 174-75 (no preemption for claim of fraud because collective agreement did not address issue); Tellez, 817 F2d at 538 (no preemption for claim of defamation because collective agreement did not envision it); Bloom, 734 F Supp at $1558 \mathrm{n} 2$ (noting exception to preemption for "claims that concern jobs not covered by a collective bargaining agreement").

Courts preempting them include Young, 830 F2d at 997; and Truex v Garnett Freightlines, Inc., 784 F2d 1347, 1351 (9th Cir 1985).

Professor Gomez refers to these as claims involving conduct outside the collective bargaining agreement. Gomez, 11 Indus Rel L J at 53-54 (cited in note 127), and notes that this is a "highly limited" exception to preemption. Id at 53. His evidence supports mine: that claims involving conduct outside the collective bargaining agreement sometimes are preempted, and sometimes are not.

${ }^{247}$ See McCormick, 934 F2d at 546 n 4 (Phillips dissenting) (noting that IIED claims are sometimes preempted, and sometimes not); Beatrice Foods, 921 F2d at 1021 (noting that circuits have reached "varying results" on the question of whether to preempt IIED claims).

Courts preempting such claims include McCormick, 934 F2d at 537; Romero $v$ Hilton Hotels, 137 Labor Rel Ref Man (BNA) at 2650; Singh, 6 IER Cases (BNA) at 1686; Beatrice Foods, 921 F2d at 1021-22; Cook, 911 F2d at 239-40; Douglas v American Information Technologies Corp., 877 F2d 565, 572-73 (7th Cir 1989); Newberry, 854 F2d at 1149-50; Hyles, 849 F2d at 1216-17; Willis v Reynolds Metals Co., 840 F2d 254, 255 (4th Cir 1988); DeTomaso v Pan American World Airways, 733 P2d 614, 620-21 (Cal 1987); Truex $v$ Garnett Freightlines, Inc., 784 F2d at 1347, 1350-51 (9th Cir 1985). See also McCormick, 934 F2d at 536 (preempting IIED claim for actions taken by employer after terminating employee).

Courts not preempting them include Perugini, 935 F2d at 1089 (no preemption of claim based on discriminatory remarks because agreement set no standards to determine outrageous conduct in that regard); Hanks, 906 F2d at 345 (no preemption of outrageous conduct and IIED claims because collective agreement provided no remedy); Sauls $v$ Union Oil Co. of California, 750 F Supp 783, $786-87$ (E D Tex 1990) (agreement provided no remedy for defendant's dealings with non-union management employees); Meier, 748 F Supp at 300 (E D Pa 1990) (no preemption of IIED claim because grievance procedure under the union contract could not redress such wrongs); Hanks, 859 F2d at 69-70; Tellez, 817 F2d at 539 (no preemption of IIED claim because the collective agreement was vague on disciplinary procedures and gave no guidance regarding the plaintiff's claim); Zaks $v$ American Broadcasting Companies, Inc., 626 F Supp 695, 698 (C D Cal 1985) (no preemption because the emotional distress was linked to clearly unpreempted claims). 
3. whistleblower claims, in which the employer fires an employee in retaliation for reporting the employer's violation of a state or federal law, and the employee sues for wrongful discharge. ${ }^{148}$

The IIED cases are particularly hard to distinguish from each other. ${ }^{149}$ One dimension upon which many of the IIED decisions can be distinguished is the degree of outrageousness of the alleged harassment. Some courts preempt when they find that the conduct alleged is not very outrageous. ${ }^{150}$ On the other hand, some courts refuse to preempt when the conduct alleged is extremely outrageous. ${ }^{151}$

${ }^{148}$ See notes $162-64$ and accompanying text. Courts that have preempted whistleblower claims include Masters v Daniel Int'l Corp., 917 F2d 455, 457 (10th Cir 1990) (employee fired for reporting safety violations at nuclear power plant); Vincent $v$ Trend Western Technical Corp., 828 F2d 563, 566 (9th Cir 1987) (employee fired for reporting employer's violation of terms of government contract); DeSoto v Yellow Freight Systems, 811 F2d 1333, 1336 (9th Cir 1987) (employee fired for refusing to drive trailer whose registration and vehicle tag had expired); Snow v Bechtel Construction, 647 F Supp 1514, 1520 (C D Cal 1986) (employee fired for reporting safety violations to Nuclear Regulatory Commission).

Courts that have not preempted them include Dougherty v Parsec, 872 F2d at 771 (employee fired for filing complaint under Occupational Safety and Health Act); Miller $v$ Fairchild Industries, 668 F Supp 461, 467 (D Md 1987) (employee fired for reporting violations of state environmental law); Brevik v Kite Painting, Inc., 416 NW2d 714, 718 (Minn 1987) (employee fired for filing complaint under state occupational safety and health act); Garibaldi $v$ Lucky Food Stores, 726 F2d 1367, 1375-76 (9th Cir 1984) (employee fired for reporting violation of state health law).

14 For example, in Truex, 784 F2d at 1344, plaintiffs claimed that their supervisors had harassed them with warning letters, and then had suspended one of them. The Ninth Circuit preempted their IIED claims because they involved administration of discipline, which was a matter covered by the collective agreement. Id at 1350 . In response to the plaintiffs' argument that under the collective agreement, warning letters were not grievable, the court held that plaintiffs were bound by contractual provisions as to when grievances may be raised as well as by contractual limitations on the available remedies. Id at 1353.

In contrast, in Sauls v Union Oil Co. of California, 750 F Supp 783 (E D Tex 1990) a worker claimed he had been harassed by his supervisor and co-workers and then fired. He filed a grievance, prevailed at arbitration, was reinstated, and then sued for IIED. The Texas District Court refused to preempt because the record indicated that the plaintiff had been subjected to a great deal of malicious and outrageous conduct, and that such conduct was not addressed in the collective bargaining agreement. Id at 788.

${ }^{180}$ In Truex, for example, the district court specifically noted that the allegations were not outrageous enough to withstand preemption. 784 F2d at 1352. See also Romero, 137 Labor Rel Ref Man (BNA) at 2649 (defendants' conduct was not sufficiently outrageous to save plaintiffs' claim from preemption).

${ }^{163}$ In Zaks, $626 \mathrm{~F}$ Supp at 698, for example, the California district court declared that "[t]he tortious conduct alleged here is so outrageous that no national labor policy would be served by preempting these claims; no federal interest would be harmed by enforcement of the state-created rights here." See also Fox, 914 F2d at 802 ("claims premised upon abusive behavior above and beyond the routine exercise of [collective bargaining] rights are not preempted"); Perugini, 935 F2d at 1089 (harassment claim not preempted where collective bargaining agreement did not establish standard for outrageous conduct). 
It is unclear why the degree of outrageousness should be a factor in $\S 301$ preemption analysis. Some courts, when using a degree-of-outrageousness factor to determine whether to preempt, cite Farmer $v$ United Brotherhood of Carpenters and Joiners ${ }^{152}$ as authority for that distinction. ${ }^{163}$ In Farmer, the Supreme Court held that the NLRA did not preempt a claim for extremely outrageous tortious conduct, because policing such conduct was so vital to local concerns that the state's interest overrode the federal interest in uniform application of the labor laws. ${ }^{154}$ However, Farmer preemption was under the NLRA, not under $\S 301$ of the Labor Relations Management Act. The Supreme Court has not ruled on whether Farmer applies to $\S 301$ preemption. The Tenth Circuit, however, has refused to rely on Farmer in a $\S 301$ preemption case, ruling that "Allis-Chalmers and Lingle, not Farmer control § 301 preemption." mains unclear.

Recently, the Seventh Circuit developed an approach to $\S 301$ preemption of IIED claims which, if adopted by other circuits, could lead to preemption of most IIED claims in the future. In Douglas v American Information Technologies Corp., an employee had been injured on her job. ${ }^{156}$ When she returned to work, she refused to work overtime or to accept certain high-stress job assignments. She claimed that, as a result of these refusals, the company engaged in a series of acts with the intent of inflicting emotional distress upon her, including denying her "stress relief days," giving her a final warning, and excessively scrutinizing her work. ${ }^{157}$

The Seventh Circuit began its analysis by enumerating the three elements necessary to establish the tort of intentional infliction of emotional distress: (1) extreme and outrageous conduct; (2) that the perpetrator intends to cause severe emotional distress; and (3) that the perpetrator does in fact cause severe emotional distress. ${ }^{158}$ It then said that to decide whether the conduct alleged is extreme and outrageous involves determining whether it was au-

152430 US 290 (1977).

${ }^{153}$ Cases that cite Farmer include Truex, 784 F2d at 1350-51; Romero, 137 Labor Rel Ref Man (BNA) at 2649.

154430 US at 302-04. Specifically, Farmer allowed a limited exception to NLRA preemption for IIED claims where the conduct complained of is "so outrageous that 'no reasonable man ... should be expected to endure it," "and where the claim does not allege discriminatory hiring hall practices. Id at 302-03 \& n 11 (citation omitted).

1ss Beatrice Foods, 921 F2d at 1021.

IsB 877 F2d 565 (7th Cir 1989).

157 Id at $567-68$.

188 Id at 570. 
thorized by an express or implied term in the collective bargaining agreement ${ }^{158}$ :

Because [the plaintiff's claim] consists of allegedly wrongful acts directly related to the terms and conditions of her employment, resolution of her claim will be substantially dependent on an analysis of the terms of the collective bargaining agreement under which she is employed. A court will be required to determine whether her employer's conduct was authorized by the explicit or implicit terms of the agreement. ${ }^{160}$

Thus the Seventh Circuit found the claim preempted.

This analysis suggests that any IIED claim that alleges wrongful acts relating to the terms and conditions of employment should be preempted under $\S 301$ on the grounds that the court could not assess the outrageousness of the conduct without determining whether the express or implied terms of the collective agreement authorize the conduct. This approach obviously would expand the number of IIED claims that are preempted. ${ }^{161}$

"Whistleblower cases" are another area where the decisions are mixed. These are cases in which an employer fires an employee in retaliation for reporting the employer's violation of a state or federal law, and the employee sues for wrongful discharge. Whistleblower cases differ from other wrongful discharge cases in that the employee bases her argument on a definite, independent public policy embodied in the law alleged to have been violated.

Some of the whistleblower cases can be distinguished on the basis of whether the violation reported is of a state or federal law. Most of the preempted claims allege retaliation for reporting a violation of a federal law. In those cases, the courts frequently preempt the claims on the basis of both $\S 301$ and the federal statute involved, under what might be called a "\$ 301-plus" preemption analysis. ${ }^{162}$

On the other hand, most of the whistleblower cases that allege retaliation for reporting violations of state law have not been pre-

1s9 Id at 571-72.

100 Id at 573 .

${ }^{161}$ For a critique of the Douglas opinion, see Note, 99 Yale L J at $222 \mathrm{n} 77$ (cited in note 116).

${ }^{262}$ See, for example, Snow, 647 F Supp at 1517-20 (preemption based both on $\$ 301$ and the Atomic Energy Act); Olguin v Inspiration Consol. Copper Co., 740 F2d 1468, 1475 (9th Cir 1984) (preemption based in part on federal statute governing mine safety). 
empted. ${ }^{163}$ These state-law whistleblower cases can be seen as applications of Lingle. Recall that the Supreme Court in Lingle refused to preempt a claim that an employee had been discharged for asserting rights under a state workers' compensation law. So too, the state whistleblower cases involve alleged retaliation for asserting rights under other state laws. ${ }^{164}$

\section{The Future of the Section 301 Preemption Doctrine}

As we have seen, in most of the areas in which states have been expanding the rights of individual employees, unionized employees who have tried to assert such rights have found their claims preempted. The only consistent exceptions are for claims that follow the fact patterns of particular Supreme Court decisions, or for issues for which the grievance procedure is not available.

In the past two years, some courts have recognized that the scope of $\S 301$ preemption is expanding to new frontiers. ${ }^{165}$ For example, in Jones $v$ General Motors Corp., a plaintiff sued for breach of an agreement between his union and his employer to settle a former grievance. ${ }^{166}$ The Sixth Circuit found the claim preempted, even though the claim implicated no term of the collective bargaining agreement. The court reasoned that resolution of the claim would not entail the interpretation of the collective bargaining agreement, but rather, would "require a court to address relationships that have been created through the collective bargaining

${ }^{103}$ See, for example, Fairchild Industries, 668 F Supp at 467 (no preemption of claim that employee was fired for reporting violations of state environmental law); Brevik, 416 NW2d at 718 (no preemption of claim that employee was fired for filing complaint under state occupational safety and health act); Garibaldi, 726 F2d at 1375-76 (no preemption of claim that employee was fired for reporting violation of state health law).

${ }^{184}$ In Gonzalez $v$ Prestress Engineering Corp., 115 Ill 2d 1, 503 NE2d 308 (1986), a pre-Lingle workers' compensation retaliation case, the Illinois Supreme Court suggested another reason why state-law whistleblower cases should not be preempted. The Court refused to preempt because to do otherwise would mean that the existence of the tort claim depended upon the interpretation of the "just cause" provision in the labor agreement. If this were the case, "the public policy of this State would become a mere bargaining chip, capable of being waived or altered by the private parties to a collective bargain." Id at 312 . See also Schwartz and Parrot, 7 St Louis U Pub L Rev at 308-09 (cited in note 104) (applying same reasoning to state whistleblower cases in general).

${ }^{185}$ See generally Committee on Labor Arbitration and the Law of Collective Bargaining Agreements, Labor Arbitration and the Law of Collective Bargaining Agreements, 7 Labor Law 747, 755-61 (1991) (noting trend toward more $\S 301$ preemption in 1990).

${ }^{168} 939$ F2d 380 (6th Cir 1991). 
process . ..."167 The court candidly admitted that this reasoning was an extension of the Allis Chalmers and Lingle tests, but said:

We have not applied a cramped and narrow construction of the dictates of Lingle and Allis-Chalmers in reaching our decisions, nor have we limited $\S 301$ preemption to cases where the precise meaning of precise words in the [collective bargaining agreement] is the crux of the state-based claim. Rather, we have found many state-based claims pre-empted because they have implicated the federal policies underlying federal labor law. ${ }^{168}$

The court then enumerated four types of claims it had preempted which did not require the interpretation of a collective bargaining agreement: (1) when "employment relationships which are subject to a collective bargaining agreement" are implicated; (2) when "the rights to be vindicated and the relationship between the parties are created not by state law, but by the collective agreement itself"; (3) "when a state-based claim requires examining the practices and customs of a workplace whose conditions are governed by a [collective bargaining agreement]"; and (4) when employees covered by a collective bargaining agreement "rely upon the existence of a separate, individual employment contract giving rise to state law claims."169

In a similar vein, in Schlacter-Jones $v$ General Telephone of California, the Ninth Circuit recently preempted a claim of unlawful drug testing. ${ }^{170}$ The court reasoned that drug testing was a working condition, and the working conditions of the plaintiff's employment were generally governed by a collective bargaining agreement. ${ }^{171}$ In fact, the court said it would have preempted the claim "whether or not [drug testing] is specifically discussed in the [collective bargaining agreement]."172

Furthermore, in Schlacter-Jones, the Ninth Circuit proposed a principle of $\S 301$ preemption that would extend it beyond what any court has yet done. In dicta, the court stated that, in a union-

167 Id at 382. See also DeSherlia v Alpha Beta Co., 1988 US App LEXIS 9378 (9th Cir) (unpublished disposition) (preempting an employee's claim that her employer breached a settlement agreement).

108 Jones, 939 F2d at 383.

169 Id (citations omitted).

170936 F2d 435, 439 (9th Cir 1991).

138 Id at 440.

172 Id (quoting Laws, 852 F2d at 433). The court also said, in a footnote, that "it is immaterial ... that no provision of the CBA explicitly deals with drug testing or gives [the company] the right to adopt drug and alcohol policies." Id at $439 \mathrm{n} 2$. 
ized workplace, claims about any working conditions that were within the scope of collective bargaining would be preempted. ${ }^{173}$ This suggestion, if accepted, would effectively seal off all unionized workplaces from state employment regulation.

In the past year, two federal judges have written powerful dissenting opinions which criticized these trends in $\S 301$ preemption. In McCormick $v$ AT\&T Technologies, ${ }^{174}$ Judge Phillips of the Fourth Circuit undertook a careful and detailed discussion of the relevant Supreme Court decisions and concluded that the cases consistently held that $\S 301$ only preempts "state-law claims [that] formally alleg[e] violations of labor contracts [or] state-law claims that can be determined to be claims for violation of laborcontracts [sic] in substance though not in form . . .."175 Accordingly, Judge Phillips argued that the Supreme Court consistently has insisted that preemption analysis focus on the "nature of the claim advanced rather than any defense put forward," and that the employers' "defensive positions are irrelevant." cluded that many federal courts had "gotten off the track,"177 and accused those courts of adopting a mistakenly expansive approach to $\S 301$ preemption, one that was rewriting the act of Congress. ${ }^{178}$

Judge Alex Kozinski of the Ninth Circuit also has delivered a dissenting opinion that challenges the broad $\S 301$ preemption doctrine. In Livadas $v$ Aubry, ${ }^{179}$ Judge Kozinski not only critized the origin of the expansive approach, but also decried its ultimate consequences. In that case, a state labor commissioner declined to prosecute the plaintiff's claim against her employer for three days

${ }^{173}$ Schlacter-Jones, $936 \mathrm{~F} 2 \mathrm{~d}$ at 441 . See also Douglas, 877 F2d at 573 (preempting IIED claim because the alleged harassment related to the terms and conditions of employment).

174934 F2d 531 (4th Cir 1991).

178 Id at 543. Judge Phillips further noted:

Where, though advanced as a tort or otherwise "independent claim," it has been apparent that the duty allegedly violated could only have been created by the labor contract, preemption has resulted, Lueck (employer's contractual duty to process insurance claims); Hechler (union's contractual duty to provide safe workplace); Rawson (union's contractual duty to make safety inspections); where the duty allegedly violated has plausibly been located "independently" of any labor contract, in general tort law or elsewhere, preemption has not resulted, Caterpillar (employer's duty under individual employee contracts); Lingle (employer's general statutory duty not to discharge retaliatorily).

Id (emphasis in original).

${ }^{128}$ Id at $543-44$.

177 Id at 544.

178 Id at 547-48.

179943 F2d 1140 (9th Cir 1991). 
pay, on the grounds that she was covered by a collective bargaining agreement. The commissioner had done so out of an honest but mistaken belief that the plaintiff's claim was preempted under $\S 301$. The plaintiff sued in federal district court under 42 USC $\S 1983$, alleging that the commissioner had interfered with her right under the NLRA to bargain collectively. The district court granted summary judgment to the plaintiff, and the commissioner appealed. ${ }^{180}$

The Court of Appeals reversed, noting that to hold otherwise "would require us to hold that she is entitled under the NLRA to a correct interpretation of California law regarding enforcement of [state employment law] claims."181 It then added:

Given the primacy of the federal scheme for handling labor disputes, we believe that Congress would not want state officials erring on the side of adjudicating state law disputes whenever it is a close call as to whether a claim is preempted. ${ }^{182}$

Judge Kozinski wrote a powerful dissent, in which he decried what he called "a novel doctrine of quasi-preemption." ${ }^{183} \mathrm{He}$ accused his colleagues of "divining some preemptive corona surrounding the federal labor laws." $184 \mathrm{He}$ argued that this approach was contrary to Supreme Court precedent as well as inconsistent with a proper judicial role. In a footnote, Judge Kozinski further argued that the quasi-preemption approach was potentially detrimental to collective bargaining:

It is not inconceivable that an employer could point to this discrepancy [between rights for unionized workers and rights for unorganized workers] as an argument against an effort to unionize: "Look here, if you vote for the union, the first thing that happens is that the state Labor Commissioner abandons you." In a closely fought election, this type of argument might make a difference. ${ }^{185}$

In sum, $\S 301$ preemption is very broad and, notwithstanding the protests of Judges Phillips and Kozinski, threatens to become even broader in the future. As a result of this expansive approach

\footnotetext{
180 Id at 1141-42.

18: Id at 1146.

182 Id at 1147.

${ }^{183}$ Id at 1148 (Kozinski dissenting).

184 Id at 1149 .

${ }^{185}$ Id at $1150 \mathrm{n} 2$
} 
to $\S 301$ preemption, unionized workers have not gotten the benefit of the explosion of individual employee rights in the past decade. ${ }^{188}$

IV. Explaining the Section 301 Preemption Doctrine: The Industrial Pluralist Conception of Collective Bargaining

Why have the courts adopted such a broad $\S 301$ preemption doctrine? The explanation cannot lie in general principles of federal preemption of state law. For, as I demonstrate in Section IV.A. below, $\S 301$ preemption is much broader than preemption in other areas of federal law. Hence we must look for an explanation unique to labor law. Toward this end, in Section IV.B., I argue that the broad $\S 301$ preemption doctrine is attributable to the industrial pluralist approach to collective bargaining that has predominated in the post-war era. Put simply, industrial pluralism conceives of labor relations as industrial self-government, in which management and labor act like political parties in a representative democracy. By this view, the workplace is an autonomous realm, resistant to the intrusion of externally-defined rights and obligations. It is this vision of labor relations that motivates the broad $\S 301$ preemption doctrine.

Finally, in Section IV.C., I consider whether $\S 301$ preemption is simply part of a larger modern trend toward private arbitration to resolve all kinds of disputes, labor and otherwise. I conclude that labor arbitration is different from other kinds of arbitration, for it extinguishes the statutory right in question. By contrast, other kinds of arbitration enforce statutory rights. In short, $\S 301$ preemption is a unique phenomenon, which can only be explained by the industrial pluralist metaphor of labor relations.

\section{A. The Unusual Breadth of Section 301 Preemption}

In many other areas, the federal courts have cut back on the scope of federal preemption. Two recent Supreme Court cases in particular express a deliberate intention to curtail federal preemption. In 1985, in Hillsborough County v Automated Medical Laboratories, the Court stated that, when states regulate health and safety, there is a presumption against federal preemption. ${ }^{187}$ And

186 Note, 99 Yale L J at 229 (cited in note 116); Herman, 9 Indus Rel L J at 638-39 (cited in note 128) (arguing that unionized workers should have the same state employment rights as do nonunion workers).

187 471 US 707, 715 (1985). 
in 1991, in Gregory v Ashcroft, the Court articulated a "clear statement" rule of preemption, which says that state regulation is only preempted when the federal legislation clearly states it was intended to have preemptive effect. ${ }^{188}$ Both of these cases indicate a trend away from federal preemption of state legislation. Even in areas of labor law preemption other than $\S 301$, the trend has been toward less preemption. ${ }^{\mathbf{1 8 9}}$

In contrast to this trend, the courts in $\S 301$ cases routinely find state claims to be preempted even when there is only the slightest shred of a federal issue involved. If ever there were a statute that lacked a clear statement of intent to preempt related state regulation, it is $\S 301$. With its bare fifty words, $\S 301$ has no ostensive content whatsoever. ${ }^{190}$ Indeed, soon after its enactment, many scholars, as well as a majority of the Supreme Court, opined that the provision was unconstitutional because it created federal jurisdiction without providing any substantive law which could be the basis of a federal question. ${ }^{191}$ In order to save the constitutionality of the statute, Justice Douglas in Textile Workers $v$ Lincoln Mills held that it authorized federal courts to develop a federal common law of collective bargaining to provide the substance. ${ }^{192}$ In other words, any federal issue that exists in an employee's state law employment claim comes not from an explicit congressional command, but rather from a vague and elusive federal common law that originated as a controversial judicial gloss on $\S 301 .^{193}$

Moreover, the courts adopted a broad interpretation of $\S 301$ preemption in the face of several narrower alternatives which were available within existing legal doctrines. For example, courts could have stayed with the well-pleaded complaint rule, and confined the preemption inquiry to the substance of the plaintiff's allegations. Such an approach would have permitted plaintiffs to vindicate

188 111 S Ct 2395, 2400 (1991) (applying clear statement rule to find no preemption of state law by Age Discrimination in Employment Act). See also Will v Michigan Department of State Police, 491 US 58, 65 (1989) ("Congress should make its intention "clear and manifest' if it intends to pre-empt the historic powers of the states.") (quoting Rice v Santa Fe Elevator Corp., 331 US 218, 230 (1947)).

189 Kosanovich, 4 Labor Law at 250-56 (cited in note 128). But see Eileen Silverstein, Against Preemption in Labor Law, 24 Conn L Rev 1, 33-52 (1991) (criticizing courts' unusually broad standard of preemption under the NLRA).

190 See note 70.

101 See, for example, Ass'n of Westinghouse Salaried Employees $v$ Westinghouse Electric Corp., 348 US 437, 447-51 (1955) (questioning whether $\$ 301$ was constitutional).

${ }^{182} 353$ US 448, 450-51 (1957).

${ }^{103}$ See id at 460-61 (Frankfurter dissenting) (accusing the Court of avoiding the "difficult problems raised by $\$ 301$. . by attributing to the section an occult content"). 
state law rights by choosing not to sue on their collective bargaining agreements. Instead, as we have seen, most courts permit the defendant to federalize a case by invoking the collective bargaining agreement in defense, notwithstanding Caterpillar.

Alternatively, courts could have ruled that when a claim is based upon state law, the fact that the claim requires some interpretation of a collective bargaining agreement does not deprive the state court of jurisdiction, or render it a $\$ 301$ claim. The Supreme Court took a parallel approach in NLRB v C \& C Plywood Corp., holding that the NLRB had jurisdiction to interpret a collective bargaining agreement when necessary to ruling on an unfair labor practice charge. ${ }^{194}$ The Court could similarily have held that, when the graveman of an action involves a state law issue, the state court has jurisdiction to decide ancillary issues, even if the court must interpret a collective bargaining agreement. ${ }^{195}$

Either of these approaches would have made state law employment rights cumulative with collectively bargained rights, and would have permitted unionized employees to enjoy the state law employment rights available to nonunion employees. Instead of adopting either of these approaches, however, the courts have adopted a predisposition, if not a presumption, to preempt.

\section{B. Industrial Pluralism}

In order to understand why the courts have chosen to adopt such a broad $\S 301$ preemption doctrine, it is necessary to see how the issue of preemption is linked with the industrial pluralist conception of collective bargaining. Industrial pluralism is a set of beliefs, doctrines, and institutions that together have dominated the interpretation of the NLRA in the post-war period. ${ }^{196}$

Industrial pluralism is based on a simple metaphor: that collective bargaining is industrial self-government. Management and labor are like political parties in a representative democracy-each represents its own constituency and, as in a legislature, engages in debate and compromise. Thus, management and labor together determine wages and working conditions through a legislative-type process. These rules are embodied in the collective bargaining agreement, which the industrial pluralist metaphor calls a statute or a constitution.

194385 US 421,428 (1967).

195 The dissent in McCormick, 934 F2d at 538-39, urges this approach.

196 See Stone, 90 Yale L J 1509 (cited in note 4); Stone, 44 Md L Rev 978 (cited in note 5 ), where I have developed this theme in more detail. 
Industrial pluralism is a descriptive and prescriptive vision of the workplace as a microcosmic constitutional democracy, a minidemocracy in the private sphere. One central aspect of the industrial pluralist metaphor is that the workplace, as a mini-democracy, has a separation of powers, and checks and balances, akin to those found in the greater political democracy. Thus, in addition to the workplace legislature-collective bargaining negotiations-and the workplace executive-management-there is a workplace judiciary-private arbitration. The role of private arbitration is to decide disputes concerning application and interpretation of the collective bargaining agreement. And, like the independent judiciary in our political system, private arbitration is supposed to provide a neutral vantage point for enforcing the rules, divorced from the power contests that went into the making of the rules in the first place. With this separation of powers, industrial pluralism portrays the workplace as a democratic institution, rather than the enclave of private power that many social critics have claimed it to be. ${ }^{197}$

The industrial pluralist vision is not merely a neutral description of the workplace. It is a description with a normative message about how collective bargaining should be structured. The picture of the workplace as an autonomous, self-sufficient, democratic realm suggests that conditions inside the workplace are fair and just. The normative message is that all is well, and that outsiders, such as legislatures, should not intervene. In addition, the picture suggests that for the autonomous mini-democracy to function it must replicate the political democracy. Thus private arbitration, rather than the outside judiciary, should be the exclusive tribunal for resolving disputes. These two programmatic consequences of the industrial pluralist conception have had a profound impact on

197 In the 1950 s and 1960 s, some democratic theorists were concerned that American society was not truly democratic because, despite the existence of democratic political institutions, most people experienced authoritarian control over one of the most important aspects of their lives-their workplace. See, for example, Robert A. Dahl and Charles E. Lindblom, Politics, Economics, and Welfare: Planning and Politico-Economic Systems Resolved into Basic Social Processes 482-83 (Chicago, 2d ed 1976) (describing the power of business managers as highly discretionary and antidemocratic); Grant McConnell, Private Power and American Democracy 251-55 (Knopf, 1966) (noting the power of the corporation and discussing the problem of its illegitimacy); Seymour Martin Lipset, Political Man: The Social Bases of Politics 273 (Johns Hopkins, exp ed 1981) (discussing the lack of "integrative participation" by American workers). See also Leon $\mathrm{H}$. Keyserling, Why the Wagner Act?, in Louis G. Silverberg, ed, The Wagner Act: After Ten Years 13 (BNA, 1945) (the American institution of collective bargaining, by introducing self-government into industry, preserves our democratic way of life) (quoting Senator Robert F. Wagner, address at National Democratic Club Forum, May 8, 1937). 
the development of the law of collective bargaining in the postwar era.

One result of industrial pluralist rhetoric is that the Supreme Court has elevated private arbitration to an exalted status within labor law doctrine. ${ }^{198}$ In a series of benchmark decisions in the late 1950 s and early 1960s, the Supreme Court adopted the pluralist rationale of defending the mini-democracy from external, particularly judicial, intervention. ${ }^{199}$ It announced a national labor policy of promoting private arbitration and adopted a policy of extreme deference to the arbitral process. ${ }^{200}$ In fact, it decreed an amount of judicial deference to labor arbitration which was much greater than the deference paid to arbitration in any other field. ${ }^{201}$ Accordingly, the Court erected a structure in which rulings by labor arbitrators were placed effectively beyond the reach of judicial review. ${ }^{202}$

The industrial pluralist interpretation of the labor laws thus had the effect of reprivatizing labor relations. It also established a rigid barrier between the workplace and external sources of law. As a result, the collective bargaining system has not been able to accommodate the proliferating individual employment rights of the 1980s.

1. Explaining the broad Section 301 preemption doctrine.

Understanding the industrial pluralist belief in the sanctity of the mini-democracy can illuminate the predisposition of judges to

\footnotetext{
198 News America Publications v Newark Typographical Union, 918 F2d 21, 24 (3d Cir 1990) (on "exalted status" of arbitration). See also United Paperworkers v Misco, Inc., 484 US 29, 37-38 (1987) (discussing need to "insulat[e] arbitral decisions from judicial review"). ${ }^{189}$ See Stone, 90 Yale L J at 1526-31 (cited in note 4).

${ }^{200}$ Lincoln Mills, 353 US at 456 (\$301 represents a national policy to enforce arbitration agreements); United Steelworkers of America v American Manufacturing Company, 363 US 564, 567-68 (1960) (courts should enforce agreements to arbitrate regardless of the merits of the specific grievance); United Steelworkers of America $v$ Warrior \& Gulf Navigation Co., 363 US 574, 585 (1960) (strong presumption of arbitrability); and United Steelworkers of America v Enterprise Wheel \& Car Corp., 363 US 593, 597-98 (1960) (Court will enforce arbitrator's judgment, even if arbitrator's opinion is ambiguous, so long as it "draws its essence from the collective bargaining agreement.").

${ }^{201}$ See notes 73-74, 221 and accompanying text.

${ }_{202}$ United Paperworkers, 484 US at 37-38. See also note 73 (on Enterprise Wheel test).

At the same time, the Court constricted the jurisdiction of the NLRB so as to make arbitration the primary, an " final, adjudicator of the statutory as well as contractual rights of organized workers. See ('arey v Westinghouse, 375 US 261, 270-71 (1964) ("If by the time the dispute reaches the Board, arbitration has already taken place, the Board shows deference to the arbitral award, provided the procedure was a fair one and the results were not repugnant to the [NLRA].").
} 
find state employment rights preempted by $\S 301$. Under the industrial pluralist view, the terms of the bargain that the parties to the mini-democracy reach, and the enforcement mechanism that the parties establish, are superior to any state-imposed employment terms. Thus it would only do harm to interfere.

To the extent that courts believe the rhetoric of industrial pluralism, they want to keep judicial scrutiny as well as external law out of the workplace as much as possible. Accordingly, they have insisted upon insulating collective bargaining from external sources of employment rights. Section 301 preemption provides them with a means to do so. ${ }^{203}$ By expanding the scope of $\S 301$ preemption, courts keep state employment law out of the unionized workplace. Thus, the unstated belief in the superiority of the mini-democracy is the driving force behind the judicial predisposition to preempt. ${ }^{204}$

${ }^{203}$ When a federal law regulates conduct within a unionized workplace, the issue is deferral, not preemption. In that area, the Supreme Court has permitted more penetration by external law. Recall that in Gardner-Denver, the Supreme Court held that an individual may bring a Title VII claim of discrimination, even though an arbitration procedure had heard and decided the same dispute. 415 US at 59-60. See note 139. The Court similarily has held that an individual may bring claims under the Fair Labor Standards Act and under $\$ 1983$ in federal court, notwithstanding a prior arbitration. Barrantine v Arkansas-Best Freight System, 450 US 728 (1981) (FLSA); McDonald v City of West Branch, 466 US 284 (1984) (§ 1983). Many management labor lawyers have found these doctrines unduly restrictive of their ability to use arbitration in lieu of litigation for employee statutory claims. See, for example, Jay W. Waks and Louis Ginsberg, Arbitrating Executive and Other Employment Disputes: Let's Put a Pin in Gardner-Denver! in 43d Annual National Conference on Labor 245, 303-05 (cited in note 24) (urging that Gardner-Denver be overturned).

In 1991, the Supreme Court decided a case that arguably cuts back on the scope of deferral to employees' federal statutory claims. Gilmer v Interstate/Johnson Lane Corp., $111 \mathrm{~S} \mathrm{Ct} 1647$ (1991), held that an individual who agreed to arbitrate all disputes concerning his employment was required to arbitrate his statutory claim under the Age Discrimination in Employment Act. Some labor lawyers and scholars are predicting that, after Gilmer, the Supreme Court will reverse Gardner-Denver. Stephen A. Mazurak, The Status of the Employment Relationship: The 1990-91 Supreme Court Term, 7 Labor Law 849, 865-66 (1991); Robert L. Duston, Gilmer v Interstate/Johnson Lane Corp.: A Major Step Forward for Alternative Dispute Resolution, or a Meaningless Decision?, 7 Labor Law 823, 834 (1991).

${ }^{204}$ See, for example, McCormick, 934 F2d at 538 ("Our holding that McCormick's state law claims are preempted by $\S 301$ protects the continued vitality of grievance procedures as a fair and efficient means for the resolution of labor disputes ...."); White, $938 \mathrm{~F} 2 \mathrm{~d}$ at 481 ("Driving the Court's decision in [Allis-Chalmers was] the need to preserve the central role of arbitration established in collective bargaining contracts."). On the close relationship between $\$ 301$ preemption and the grievance and arbitration system, see also Beatrice Foods, $921 \mathrm{~F} 2 \mathrm{~d}$ at 1020 (Allis-Chalmers consistent with broad policy favoring arbitration that the Supreme Court stated in The Steelworkers Trilogy). See also Clyde W. Summers, Labor Law as the Century Turns: A Changing of the Guard, 67 Nebr L Rev 7, 20 (1988) (decisions like Allis-Chalmers "cast a cloud" over possibility of unionized workers using state courts to remedy wrongful dismissals, thereby preserving "central role of arbitration in interpreting the [labor] contract"). 
An example will illustrate this point. In Jackson $v$ Liquid Carbonic Corp., an employee had been terminated after he had tested positive in an employer-instituted drug testing program. ${ }^{205} \mathrm{Al}$ though he was covered by a collective bargaining agreement, he elected to sue in state court on the basis of a state privacy statute and the state constitutional right to privacy. The employer argued that the claim was preempted, removed to federal court, and moved to dismiss. ${ }^{206}$

In analyzing the preemption issue, the court had to interpret the state law. At the time, the state law was new, so it had not yet been interpreted by the state courts. The First Circuit interpreted the state law not as imposing an absolute prohibition on drug testing, but rather as calling for a balancing test-between the employee's right to privacy and the employer's legitimate interest in conducting the test. ${ }^{207}$ Thus it said that the statute prohibited "only unreasonable interferences with a person's privacy."208 The court concluded that to perform the balance and to decide what was reasonable required the court to interpret the collective bargaining agreement. ${ }^{208}$ More specifically, what was reasonable regarding drug testing had to be

assessed in light of the practices and exigencies of the industry, factors which are routinely considered when interpreting a collective bargaining agreement. [Therefore plaintiff's privacy claim is] inseparable from an interpretation of what is or is not 'reasonable' under the labor contract. . . . [It is] both negotiable and bound up in the interstices of the Agreement .....210

The collective bargaining agreement contained a clause that gave management a right "to post reasonable rules and regulations

205863 F2d 111, 112-13 (1st Cir 1988).

206 Id at 113.

207 Id at 115-16.

${ }^{208}$ Id at 116 (quoting Bratt $v$ International Business Machines Corp., 392 Mass 508, 467 NE2d 126, 135 (1984)).

${ }^{209}$ Significantly, the court admitted that the state courts had not yet addressed the issue of employee drug testing. But it surmised that the state courts "would view the collective bargaining process as an appropriate datum in constructing the needed balance between the worker's privacy rights and the legitimate concerns of management." Id at 117. "A right subject to a balance involving the needs and interests of the parties is, almost of necessity, defined by the parties themselves." Id.

210 Id at 119. Later the court reiterated that, in determining reasonableness under the state privacy statute, it did "not see how, under state law, the Agreement can be omitted from the equation." Id at 121. 
from time to time."211 This, the court said, established a sufficient nexus between the drug testing and the collective agreement to preempt the employee's claim. ${ }^{212}$ Embellishing upon this reasoning, the First Circuit went on to note the central role of arbitration in the system of industrial self-government, and ultimately concluded that to permit this plaintiff to sue on a state law claim "would surely undermine the structure of industrial selfgovernment." 213

There are three problems with the First Circuit's analysis. First, the court found that the state right required balancing. However, the state right might not have required balancing at all-it might have been an absolute prohibition of employer drug testing. In that event, there would be no room for the collective bargaining agreement to limit, define, or waive the state law right. The court could have certified this question to the state court rather than interpreting the state law in the first instance. ${ }^{214}$

Second, the court did not give a convincing account as to why the employer's right to make reasonable rules had any bearing on the plaintiff's privacy claim. The dissent argued that the management rights clause in the collective agreement was far too general and vague to support preemption of this particular claim, ${ }^{215}$ evidently interpreting the clause giving management the right to make "reasonable rules and regulations" as boilerplate. In the face of explicit rules imposed from without, the dissent said, the employer-made rules should yield. The dissent concluded that, even if the state statute required balancing, the balancing inquiry was not necessarily bound up with the collective agreement. ${ }^{216}$

The third and most significant problem with the First Circuit's reasoning was that it did not explain why the contractual provision giving the employer the right to make "reasonable rules and regulations from time to time" trumped state law. That is, even if the state law did call for balancing, the court assumed that, in the balance, the employer's rules outweighed the legislature's rules. In essence, the court was saying that the rules made within

211 Id at 113.

212 Id at 119.

213 Id at 121-22.

214 See Note, 40 Syracuse L Rev at 1296 (cited in note 119) (suggesting that the Jackson court should have taken this approach).

21s 863 F2d at 122 (Bownes dissenting) ("In the instant case, there [was] nothing in the collective-bargaining agreement which even remotely deal[t] with the subject of drug testing or privacy rights.").

${ }^{216}$ Id at 124. 
the mini-democracy were superior to those of external law. Presumably the court believed that because parties had bargained to give management the right to make reasonable rules, the rules imposed by the state legislature should yield. The court could have assumed, to the contrary, that the employer's contractual right to make rules must be exercised consistently with state law.

In short, the relationship between the bargained-for right of management to make "reasonable rules" and the specific requirements of state law depends upon assumptions about the superiority vel non of the mini-democracy. The Jackson case exemplifies a favorable view of the industrial pluralist mini-democracy. In that view, the rules of the autonomous world of the unionized workplace are superior to external law. If those rules vest management with discretion in a particular area, then management is free to exercise that discretion, despite restrictions imposed by a state legislature.

Even in the absence of an explicit contractual provision giving management the right to make "reasonable rules," many courts have said that such a provision might be implied. ${ }^{217}$ It is increasingly common for courts to recognize the possibility that a collective agreement contains implied terms, particularly terms that grant discretion to management. ${ }^{218}$ Such an implied term, under the Jackson court's reasoning, would preempt a state law right, even in the absence of any contractual language on the subject.

The industrial pluralist assumption about the superiority of the mini-democracy explains not only the courts' expansive approach to $\S 301$ preemption, but also the exceptions to $\S 301$ preemption that were described above. As we saw, courts find that most claims by unionized workers invoking state employment rights are preempted. There are exceptions for the cases presenting the precise fact patterns which the Supreme Court has already addressed, and for claims not cognizable under the grievance procedure. The industrial pluralist assumption that the mini-democracy is superior to external law explains this latter exception. When a plaintiff cannot bring a claim within the internal judiciary of the workplace, there is no reason to preempt.

\footnotetext{
${ }^{217}$ See, for example, Douglas, 877 F2d at 572-73.

${ }^{218}$ See, for example, Consolidated Rail Corp. v Railway Labor Executives' Ass'n, $109 \mathrm{~S}$ Ct 2477, 2485 (1989) ("Conrail"). See also Katherine Van Wezel Stone, Labor Relations on the Airlines; the Railway Labor Act in the Era of Deregulation, 42 Stan L Rev 1485, 151322 (1990); Harry Shulman, Reason, Contract, and Law in Labor Relations, 68 Harv L Rev 999, 1010-16 (1955).
} 
2. Limitations of the mini-democracy.

The industrial pluralist conception of collective bargaining forces workers to choose between contractual rights which they can obtain in a union setting, or statutory rights, which they can obtain in a nonunion setting. Because workers often can achieve superior substantive rights in the collective bargaining context than they have under external law, one could argue that the loss of statutory rights is more than compensated by the gain in contractual rights. This argument would be true if unions in fact achieve superior rights in collective bargaining, and if unions can effectively enforce those rights in the grievance and arbitration system. The latter precondition is problematic.

Despite its rhetoric of providing workplace democracy, the arbitration system has not provided a satisfactory means for workers to enforce collectively bargained employment rights. ${ }^{\mathbf{2 1 9}}$ Arbitration is ineffective partly because it does not provide the due process protections available in a public tribunal, be it a court or an administrative agency. As Justice Brennan has said,

Arbitral factfinding is not generally equivalent to judicial factfinding. ... "[T] The record of the arbitration proceedings is not as complete; the usual rules of evidence do not apply; and rights and procedures common to civil trials, such as discovery, compulsory process, cross-examination, and testimony under oath, are often severely limited or unavailable."220

In addition, there is no effective right of appeal. ${ }^{221}$

Furthermore, remedies in arbitration are not as effective or as generous as remedies in a judicial forum. For example, most arbitrators believe that they do not have the power to award damages for intangible harms, or to award punitive or consequential dam-

\footnotetext{
219 See Stone, 90 Yale L J at 1529-30 (cited in note 4); Atleson, 11 NYU Rev L \& Soc Change at 95 (cited in note 44).

${ }^{220}$ McDonald $v$ West Branch, 466 US 284, 291 (1984) (quoting Gardner-Denver, 415 US at 57-58).

${ }^{221}$ The Supreme Court has propounded an extremely narrow standard of review for labor arbitration. In Enterprise Wheel, the Court said that an arbitral award should be overturned only if it failed to derive its essence from the agreement. 363 US at 597. It also said that mere ambiguity about the essential foundation of the award would not be grounds for overturning the award. Id at 598. The "essence test" combined with the "presumption of arbitral regularity" have rendered judicial review of arbitrator rulings practically unobtainable. See Peter Feuille and Michael LeRoy, Grievance Arbitration Appeals in the Federal Courts: Facts and Figures, 45 Arb J 35, 40-45 (Mar 1990) (since the Steelworkers Trilogy in 1960 , less than $1 \%$ of all arbitral awards have been challenged in court, and of those challenged, almost three-quarters have been upheld).
} 
ages. ${ }^{222}$ In addition, arbitrators almost never grant interest on back pay awards, even when they are issued months or years after an unjust dismissal. ${ }^{223}$ It is common practice for an arbitrator to award reinstatement but no back pay at all to a worker fired without just cause. ${ }^{224}$ In contrast, prevailing parties in unjust dismissal litigation receive jury awards in the mid to high six figures. ${ }^{225}$ Furthermore, most arbitrators believe that they do not have the power to order provisional relief. ${ }^{226}$ Thus many contract violations, such as improper job assignments or safety matters, can neither be prevented nor remedied after the fact. In addition, arbitrators do not provide the accountability of a public forum. They are not bound by precedent, their awards are rarely published, the hearings are not held in open court, and arbitrators are not public officials accountable to public pressures and sworn to uphold public policies. $^{227}$

Thus the legacy of industrial pluralism has been to weaken the employment rights of unionized workers within the mini-democracy by not providing adequate means for their enforcement. At

${ }^{222}$ Frank Elkouri and Edna Asper Elkouri, How Arbitration Works 401-06 (BNA, 4th ed 1985); Otis H. King, How Whole is Whole?: Remedies in Labor Arbitration, $3 \mathrm{~J}$ Contemp Legal Issues 167, 169-73 (1989-90) (on reluctance of arbitrators to award consequential damages); E. Allan Farnsworth, Punitive Damages in Arbitration, 20 Stetson L Rev 395, 400-01 (1991) (speculating about why arbitrators might be reluctant to award punitive damages). See also Note, Protecting Intangible Expectations Under Collective Bargaining Agreements-Overcoming the Proscription of Arbitral Penalties, 61 Minn L Rev 127, 128 (1976) (urging arbitrators to use penalties to protect employees' intangible interests in their labor contracts).

${ }^{223}$ See, for example, Intermountain Operators League, 26 Labor Arb (BNA) 149, 154 (1956) (Kadish, Arbitrator) ("II]t is not customary in arbitrations for the arbitrator to grant interest on claims which he finds owing.").

${ }^{224}$ King, $3 \mathrm{~J}$ Contemp Legal Issues at 171 (cited in note 222); Howard Lesnick, Response, 11 NYU J L \& Soc Change 142, 145 (1982-83).

${ }^{225}$ A study of 121 awards in wrongful discharge litigation in California between 1980 and 1986 found that prevailing plaintiffs won, on average, $\$ 650,000$ in the initial jury award, of which about $40 \%$ was for punitive damages. It also found that the median award was $\$ 177,000$. James Dertouzos, Elaine Holland, and Patricia Ebener, The Legal Consequences of Wrongful Termination vii (Rand Institute for Civil Justice, 1988). This figure may somewhat overstate the comparison because many of the prevailing plaintiffs in the Rand study were middle-level managerial employees, whose salary, and hence back pay, is higher than that of most union members. See also Cliff Palefsky, Wrongful Termination Litigation: "Dagwood" and Goliath, 62 Mich Bar J 776 (1983) (discussing a 1982 study finding that $90 \%$ of California discharge cases that went to trial resulted in verdicts for plaintiff, and that the average award on these verdicts was $\$ 450,000$ ).

${ }^{226}$ Elkouri and Elkouri, How Arbitration Works at 401-02 (cited in note 222).

${ }^{227}$ Stone, 90 Yale L J at 1529-30 (cited in note 4). See also Owen M. Fiss, Against Settlement, 93 Yale L J 1073, 1085-87 (1984) (criticizing alternative dispute resolution because its aim is to provide peace rather than justice, thereby sacrificing important public values). 
the same time, the industrial pluralist ideology has fueled the trend toward expansive $\S 301$ preemption. It has both hindered unionized workers' ability to implement their contractual rights and deprived them of employment rights under external law.

\section{The historical development of industrial pluralism.}

These limitations of collective bargaining were not apparent until the 1970s and 1980s, when unorganized workers began to receive legislative and judicial assistance in the form of the explosion of individual employee rights. Until then, whatever rights were available to unionized workers through the bargaining and arbitration system were the only rights workers had, so there was no standard by which to measure such rights. But now, the proliferation of state employment rights, together with the current $\S 301$ preemption doctrine, means that collectively bargained rights are not always better.

One might ask, how could this system of collective bargaining have flourished for so long if it is indeed destructive of union strength? Here some historical perspective is helpful.

Industrial pluralism developed in the postwar years, at a time when an expanding economy and United States dominance in the world led to a rising standard of living for most Americans and a general feeling of optimism about the future. Part of this optimism included the view that employers would come to accept unionism, that the scope of bargaining between management and labor would continually expand, and that unions would come to play greater and greater roles in corporate decisionmaking. ${ }^{228}$ In an environment of economic expansion, stable markets and thriving companies, job security was not a particularly pressing concern. Collective bargaining about such items as wages, seniority, pensions, and so forth was sufficient to protect workers' interests. In the first decades after World War II, unions successfully negotiated regular wage increases, established health and pension benefit programs, and protected employees against arbitrary treatment. ${ }^{229}$ For a workforce that recently had experienced the Great Depression and the wage freezes of World War II, these were enormous accom-

228 See Kochan, Katz, and McKersie, Transformation of American Industrial Relations at $45-46$ (cited in note 34) (describing optimism of the postwar period).

${ }^{228}$ See Neil W. Chamberlain, The Union Challenge to Management Control 74-88 (Harper, 1948) (describing union penetration of traditional managerial areas such as wages, hours, advancement policies, health and safety, disciplinary control, hiring practices, and layoffs). 
plishments. Thus industrial pluralism was helpful to unions because it forced employers to deal with them about issues of importance to their members. ${ }^{230}$

At the same time, the analogy of the workplace to a mini-democracy gave the labor movement a mantle of respectability in the public mind-a mantle that it never before had, and since has lost. This mantle paid off in real terms: In strike situations, the public was loathe to cross picket lines and the unemployed were loathe to accept jobs as replacements. Thus the high public esteem of organized labor played a role in strengthening the labor movement.

Labor's demise in the public mind paralleled the demise of union strength. Throughout the 1950s and 1960s, well-publicized stories of labor corruption and scandal turned public opinion away from labor. ${ }^{231}$ Other social causes like the civil rights movement and the anti-war movement captured the hearts and minds of the liberal intelligentsia. At the same time, industrial pluralism's emphasis on the mini-democracy led unions to focus their attention on plant-specific or company-specific gains, and to refrain from developing strategies or coalitions with other groups to achieve broader legislative goals.

The decade of the 1980s was a watershed for American workers in several respects. First, in that decade there was a distinctly sharper rate of membership decline, a decline so pronounced that some scholars predicted the end of organized labor as a significant force on the American scene. ${ }^{232}$ At the same time, the dramatic corporate transformations of the decade produced correspondingly dramatic employee dislocations. ${ }^{233}$ This led to a public climate which was receptive to, if not insistent upon, some protection for

${ }^{230}$ Kochan, Katz, and McKersie, Transformation of American Industrial Relations at 45-46 (cited in note 34) (New Deal System of labor relations worked well until the 1970s).

${ }^{233}$ For an account of the declining esteem of organized labor amongst the public at large from the 1940s through the 1960s, see Derek Curtis Bok and John Thomas Dunlop, Labor and the American Community 15-19 (Simon \& Schuster, 1970).

${ }^{232}$ See note 8 and accompanying text. Paul Weiler has given data suggesting that, by the year 2000, unions would represent less than $10 \%$ of the American private sector workforce. Weiler, Governing the Workplace at 10 (cited in note 27). See also Troy, $59 \mathrm{U}$ Chi L Rev at 683 (cited in note 12) (estimating 7\%). But see McDonald, 31 Indus Rel at 15 (cited in note 10) (Assistant to the Secretary-Treasurer of the AFL-CIO) (disputing Weiler's projection and arguing that unions probably would not decline as sharply in 1990s as in 1980s).

${ }^{233}$ There is considerable disagreement about whether takeovers and corposate restructurings actually cause net job loss. See Stone, 21 Stetson L Rev at $45 \mathrm{n} 4$ (cited in note 66) (summarizing debate). Whether the case can be made or not, however, the AFL-CIO believes that takeovers cause massive job loss. See note $\mathbf{3 5}$ and accompanying text. Large sectors of the American public share that belief. 
the job security of individual employees. The legislative and judicial protections that have resulted, while minimal, have begun to rival the protection offered by unions.

Under a different system of collective bargaining, the new legislation and judicial protections for employees might have been cumulative with collective bargaining. ${ }^{234}$ But under the industrial pluralist system, there was no place for state-created rights.

C. Industrial Pluralism and the Trend Toward Private Arbitration

One could argue that expansive $\S 301$ preemption, while unfortunate for labor, derives not from a particular view of collective bargaining, but rather from a larger trend toward alternative dispute resolution in the legal system generally. For example, one could argue that the $\S 301$ preemption trends are no different from recent developments in the areas of securities, antitrust, and age discrimination, where the Supreme Court has been expanding the role of private arbitration.

In a series of decisions in the 1980s, the Supreme Court held that many types of judicially cognizable claims are subject to arbitration under the Federal Arbitration Act (the "FAA"). ${ }^{236}$ In 1983, in Moses H. Cone Memorial Hospital v Mercury Construction Corp., the Supreme Court found that a state law claim for breach of contract was subject to arbitration by virtue of an arbitration clause in the parties' agreement. ${ }^{236}$ In language reminiscent of The Steelworkers' Trilogy, the Court said that

[t]he Arbitration Act establishes that, as a matter of federal law, any doubts concerning the scope of arbitral issues should be resolved in favor of arbitration, whether the problem at

\footnotetext{
${ }^{234}$ For example, in western Europe, the welfare state measures enacted in the postwar era were compatible with collective bargaining. See, for example, Charles S. Maier, "Fictitious bonds ... of wealth and law": on the theory and practice of interest representation, in Suzanne Berger, ed, Organizing Interests in Western Europe: Pluralism, Corporation, and the Transformation of Politics 27, 54-55 (Cambridge, 1981) ("Fictitious Bonds").

${ }^{238}$ See, for example, Mitsubishi Motors v Soler Chrysler-Plymouth, 473 US 614, 640 (1985) (Sherman Act claims); Shearson/American Express v McMahon, 482 US 220, 238, 242 (1987) (claims under $\$ 10(b)$ of the Securities Exchange Act of 1934 and RICO); Rodriguez de Quijas v Shearson/American Express, 490 US 477, 480 (1987) (claims under the Securities Act of 1933); Gilmer v Interstate/Johnson Lane Corp., $111 \mathrm{~S} \mathrm{Ct} 1647,1657$ (1991) (ADEA claim).

${ }^{236} 460$ US 1, 24-25 (1983).
} 
hand is the construction of the contract language itself or an allegation of waiver, delay, or a like defense to arbitrability. ${ }^{237}$

In 1985, the Supreme Court found claims arising under the federal antitrust laws to be subject to mandatory arbitration under the FAA. In Mitsubishi Motors v Soler Chrysler-Plymouth, the Court invoked the presumption of arbitrability and ordered the parties to arbitrate claims arising under the Sherman Antitrust Act, even though their arbitration agreement did not explicitly apply to statutory claims. ${ }^{238}$ The Court said that, so long as the parties even arguably had agreed to arbitrate the statutory issue, and so long as Congress had not intentionally removed the statutory issue from arbitration, the parties were required by the FAA to submit to arbitration. ${ }^{239}$ Since then, the Supreme Court has ordered arbitration of other federal statutory claims, including claims for securities act violations, civil RICO claims, and age discrimination claims. ${ }^{240}$

The rise of arbitration in non-labor areas thus seems to parallel the rise of arbitration in the labor area twenty-five years earlier. Indeed, in Mitsubishi, the Court drew support from labor law cases for the presumption of arbitrability it applied to the Federal Arbitration Act. ${ }^{241}$ However, there is a crucial difference between the new wave of arbitration under the FAA and labor arbitration under $\S 301$. When the FAA compels arbitration of a statutory issue in a non-labor context, the issue for the arbitrator to decide is the statutory right in dispute. For example, in Mitsubishi, the issue to be arbitrated was the application of the Sherman Antitrust Act to the respondent's alleged behavior. The arbitration clause only functioned to indicate the parties' choice between an arbitral or judicial forum. As the Supreme Court said in Mitsubishi, "[b]y agreeing to arbitrate a statutory claim, a party does not forgo the substantive rights afforded by the statute ...."242 In keeping with the FAA arbitrator's responsibility to enforce the parties' substan-

237 Id.

238 473 US $614,624-26,640$ (1985).

238 Id at 626-28.

${ }^{240}$ McMahon, 482 US at 238 (Securities Exchange Act of 1934 and civil RICO); Rodriguez de Quijas, 490 US at 480 (Securities Act of 1933); Gilmer, 111 S Ct at 1657 (ADEA). ${ }^{241}$ See Mitsubishi, 473 US at 626, citing Warrior \& Gulf, 363 US at 582-83.

$242473 \mathrm{US}$ at 628 . See also Volt Information Sciences $v$ Board of Trustees, $109 \mathrm{~S} \mathrm{Ct}$ 1248, 1255 (1989). 
tive rights under the statute at issue, courts vacate awards when the arbitrator has shown "manifest disregard of the law."243

In contrast, an arbitration requirement under $\S 301$ does not involve merely a change in the forum for resolving a statutory dispute. Rather, labor arbitrators are required to decide cases by interpreting the collective bargaining agreement, not by interpreting external law. ${ }^{244}$ Thus, despite the superficial similarity between $\S 301$ and FAA arbitration, the two types of arbitration are entirely different. Arbitration under the FAA enforces statutory claims; arbitration under $\S 301$ extinguishes statutory claims. Section 301 preemption cannot be understood as part of the general tendency by the courts to move statutory issues into arbitral tribunals. Rather, it must be understood as part of the unique and uneasy relationship between the labor law system and external law.

\section{Evaluating the New System of Labor Regulation}

So far I have shown that the current system of labor relations in the United States creates a tension between collective bargaining and individual employment rights. As collective labor rights have declined, and as states have sought to compensate by strengthening individual employee rights, the broad § 301 preemption doctrine has placed union workers at a disadvantage relative to nonunion workers, by denying the former the benefit of the state law employment rights. I have also shown that $\S 301$ preemption cannot be explained as part of the general trend of the past decade to refer statutory claims to arbitration. Rather, I have argued that the broad $\S 301$ preemption doctrine must be understood as an aspect of the industrial pluralist interpretation of the labor laws, an interpretation that relies on a sharp distinction between contractual rights and statutory rights, between collective bargaining and external law. By so embracing industrial pluralist forms of collective bargaining, the current system of labor relations in the United States sets up a dichotomy between collective bargaining and individual employment rights.

\footnotetext{
${ }^{243}$ See, for example, McMahon, 482 US at 232 (judicial review of FAA arbitration "is sufficient to ensure that arbitrators comply with the requirements of the statute"). See C. Evan Stewart, Securities Arbitration Appeal: An Oxymoron No Longer?, 79 Ky L J 347, 351-55 (1990-91) (history of the "manifest disregard of the law" standard); Comment, Overcoming the Presumption of Arbitrability of ADEA Claims: The Triumph of Substantive over Procedural Values in Nicholson v. CPC International, Inc., 138 U Pa L Rev 1817, 1824 (1990).

24. See note 74 on arbitrators' use of external law.
} 
We are thus left with several normative questions: First, are workers better off dispensing with collective bargaining and instead seeking workplace justice under the emerging regime of individual rights? Second, can we conceive of alternative legal regimes in which collective and individual employment rights are compatible and mutually reinforcing? Third, do the developments in Section 301 preemption and the legal incompatibility between unionism and individual rights play a role in union decline? I will address each of these questions below.

A. The Minimal Terms/Individual Rights Model of Labor Relations

The growth of individual employment rights and the reduction in protection for collective bargaining suggest that the emerging system of labor regulation is one in which there are legislatively and judicially imposed minimal terms of employment, without collective bargaining. I call this the individual rights/minimal terms model of labor relations.

If the emerging system of individual employment rights does in fact provide universal employment rights, then it is plausible that most workers would benefit by dispensing with collective bargaining altogether. That is, perhaps individual workers have regained legislatively what they have lost in collective bargaining, so that on balance they have not been harmed by the broad $\S 301$ preemption doctrine and the decline of unions.

Professor Charles Fried has been a spokesman for this point of view. Professor Fried has advocated that we move "toward direct imposition of specific minimal terms and standards where problems in the workplace have been perceived [and] away from governmentally sheltered monopoly status for labor unions." 245 Unemployment insurance, workplace safety regulations, anti-discrimination protection, and protection against unjust dismissal are laudatory examples of such minimal terms. ${ }^{246} \mathrm{He}$ argues that, without collective bargaining, the law could achieve the larger goals of ensuring free association, a social minimum level of resources, job security, industrial democracy, dignity on the job, allocative efficiency and industrial peace. ${ }^{247}$

\footnotetext{
${ }^{245}$ Fried, 51 U Chi L Rev at 1040 (cited in note 4).

${ }^{248}$ Id at 1036-37.

247 Id at 1020-21.
} 
While Professor Fried's approach seems to describe the trends we have seen in the law, there are several problems with his normative conclusions: First, providing individual employment rights without a union does not allow employees to participate in corporate decisionmaking. To the extent that we value not only minimal employment standards but also the opportunity for employees to have a say about workplace issues that concern them, the nonunion rights model is not an adequate substitute. ${ }^{248}$

Second, there is some evidence that productivity improves when employees have an avenue for expressing discontent with voice rather than exit. ${ }^{249}$ Some nonunion firms have established internal grievance mechanisms to gain the benefits of a voice mechanism without incurring the costs and disadvantages of having a union. ${ }^{250}$ However, some have argued that such mechanisms, when not truly independent, ultimately breed distrust, cynicism, and low morale. ${ }^{251}$

Third, minimal terms are too uniform and rigid to address the preferences of employees at all workplaces; they cannot accommodate local differences. Therefore they are not a particularily efficient way to improve wages and working conditions. ${ }^{252}$ They can provide basic minima, but above a very low level they cannot provide meaningful improvements. ${ }^{253}$

Fourth, minimal terms often are not effective. For example, the Occupational Safety and Health Act of 1970 directed the Labor Department and the National Institute of Safety and Health to set standards for all potentially hazardous industrial substances in use, to apply to all workplaces. ${ }^{254}$ Such a project is so vast, and the interests affected so varied, that today, twenty years after the enactment of the legislation, standards have only been set for a small number of the tens of thousands of industrial chemicals in com-

\footnotetext{
248 Summers, $67 \mathrm{Nebr}$ L Rev at 26 (cited in note 204).

24. Richard B. Freeman and James L. Medoff, What Do Unions Do? 162-80 (Basic, 1984).

${ }_{250}$ Sanford M. Jacoby, Employing Bureaucracy: Managers, Unions, and the Transformation of Work in American Industry, 1900-45 257 (Columbia, 1985).

${ }^{251}$ See Mike Parker and Jane Slaughter, Choosing Sides: Unions and the Team Concept 222-23 (South End, 1988).

${ }^{262}$ See Steven L. Willborn, Individual Employment Rights and the Standard Economic Objection: Theory and Empiricism, 67 Nebr L Rev 101, 109-27 (1988).

${ }^{263}$ See Susan Rose-Ackerman, Progressive Law and Economics-And the New Administrative Law, 98 Yale L J 341, 364-66 (1988) ("In more general cases regulation is likely to reduce employment levels and the real value of take-home pay . . ...").

${ }^{234}$ Pub L No 91-596, 84 Stat 1590, codified at 29 USC $\$ \S 651$ et seq (1988).
} 
mon use. ${ }^{255}$ As a result, the effort to establish minimal terms at the national level has left most workplaces without any terms at all. ${ }^{256}$

The fifth and final flaw in the individual rights/minimal terms model is that it is inherently unstable. Any improvements in protections for individual employees that occur without the presence of a strong union movement are vulnerable and transitory. This is because employees who are not in unions are not organized into a political constituency that can protect the minimal terms in the future. Without an organized constituency, any minimal terms enacted can always be repealed or negated through judicial interpretation.

Within a democratic polity, if there is no organized constituency that can articulate and advocate the interests of a segment of the population, those interests almost certainly will be ignored. This is true whether the polity is conceived to be a pluralistic competition of interest groups or a republican search for a common public good. As the labor movement continues to decline, there may soon be no organized pressure group that is capable of defending or improving individual employment rights in the future. Thus the individual rights/minimal terms model of labor relations contains a built-in self-destruct dynamic. It functions to disorganize labor, to prevent the very group-formation that is necessary, to retain or improve the minimal terms. For that reason, the individual rights and minimal terms in this model have an inherent tendency to disappear. ${ }^{257}$

\section{B. Alternative Nonpluralist Forms of Collective Bargaining}

If the minimal terms/individual rights model of labor regulation is not a reliable means of providing workplace justice, then we must ask whether there exist forms of labor regulation based upon collective rights that do not reinstate the failures of industrial pluralism. Elsewhere I have described two such models-one actual and one imagined-and I briefly summarize them below. The actual one is that of the Railway Labor Act, as it existed from 1926

${ }^{265}$ See John M. Mendelhoff, The Dilemma of Toxic Substance Regulation: How Overregulation Causes Underregulation at OSHA 74-78 (MIT, 1988).

${ }^{258}$ Id at 74-102. See also Cass Sunstein, After the Rights Revolution 82 (Harvard, 1990) (OSHA ineffective).

${ }^{267}$ Professor Richard Epstein has advocated a "no rights" form of labor regulation, in which workers have neither protection for collective bargaining nor individual employment rights. He justifies this as furthering economic efficiency. See Richard Epstein, In Defense of Contract-at-Will, 51 U Chi L Rev 947 (1984); Richard Epstein, A Common Law of Labor Relations: A Critique of the New Deal Labor Legislation, 92 Yale L J 1357 (1983). 
until recent judicial attempts to dismantle it. ${ }^{258}$ The imagined one is an expanded bargaining model, based on a nexus-of-contracts view of the firm.

\section{The Railway Labor Act model.}

The Railway Labor Act (the "RLA"), ${ }^{268}$ which governs labor relations in the airline and railroad industries, establishes a form of employee representation and collective bargaining that does not treat the workplace as an insulated realm. Rather, the RLA calls upon courts to play an active role in ensuring that management and labor jointly determine working conditions. The RLA presumes that all existing conditions and practices are the product of agreements between management and labor. Moreover, it presumes that all existing conditions and practices will continue indefinitely unless and until either management or labor wants to make a change. ${ }^{260}$ Management and labor must negotiate any such change before it can be implemented.

The procedure for making a change is specified in Section 6 of the RLA: A party seeking to make a change must serve on the other a Notice of Intent to Change Existing Conditions (a "Section 6 Notice"). ${ }^{261}$ The service of the Notice triggers an obligation for both parties to meet and discuss the proposed change; it also forbids either one to alter the status quo while the conferences go on. ${ }^{22}$ Thirty days after the end of the conferences, however, both parties can take unilateral action. The union can strike and the employer can change a working condition.

Courts enforce the status quo requirement with injunctive remedies. The status quo period is, in the words of the Supreme Court, "purposely long and drawn out," so that the pressure of the passage of time helps resolve the dispute. ${ }^{263}$ The party who wants to make a change, faced with the possibility of substantial delay,

\footnotetext{
${ }^{258}$ See Stone, 42 Stan L Rev at 1513-37 (cited in note 218) (describing judicial attempts to dismantle RLA).

${ }^{258} 45$ USC $\S \S 151$ et seq (1982 \& Supp 1987).

${ }^{280}$ See Stone, 42 Stan L Rev at 1496-98 (cited in note 218) (describing RLA bargaining and impasse procedures).

26145 USC \& 156.

${ }^{282}$ If no agreement is reached, then a mediator is assigned and the conferences continue. If and when the mediator concludes that further meetings would be futile, he declares an impasse and offers the parties final and binding arbitration. If either party declines, then the mediator terminates his efforts and a 30-day count-down period begins. Id.

${ }^{283}$ Detroit \& Toledo Shore Line R.R. Co. v United Transportion Union, 396 US 142, 149 (1969).
} 
has an incentive to compromise or give the other side something it wants in return. ${ }^{264}$

Congress inserted this system of settling disputes into the Railway Labor Act in 1926. It was designed to compel collective decisionmaking and to reduce the incentives to strike. The power to compel the other side to maintain the status quo was seen as a substitute for the power to strike. ${ }^{265}$

The RLA has proven to be particularily helpful to unions in their efforts to influence strategic-level corporate decisions, such as decisions to introduce new technology or to transform the corporate enterprise. With time and the pressure of the status quo on their side, unions have often negotiated for outcomes that either altered the employer's initial decision or cushioned its impact on union members. In numerous cases-for instance, when carriers have sought to close part of their operations, to automate and displace existing job categories, or to transfer work to a nonunion affiliate-courts have imposed bargaining obligations and a judicially enforceable status quo. ${ }^{286}$

Under the RLA, either side can invoke judicial power to enforce the status quo obligations. In defining the status quo, a court must determine whether there were past practices, implied contract provisions, or implied waivers of discretion that support either side's claim as to what constitutes the status quo. Thus the structure of the RLA calls for substantial judicial intrusion into the details of company policy and industrial life.$^{267}$ In the course of

\footnotetext{
261 Id at 150.

${ }^{265}$ See Stone, 42 Stan L Rev at 1498-99 (cited in note 218) (history of the Section 6 procedures and the status quo requirement).

${ }^{286}$ See, for example, Order of Railroad Telegraphers $v$ Chicago \& North Western $R$. Co., 362 US 330, 341-42 (1960) (holding that railroad's decision to close obsolete and unprofitable stations and to lay off some agents and telegraphers was subject to bargaining and status quo obligation); Southern Ry. Co. v Brotherhood of Locomotive Firemen, 337 F2d 127, 132-33 (DC Cir 1964) (enjoining effort by railroad to eliminate firemen on trains and to cease hiring new firemen); Ruby v TACA International Airlines, 439 F2d 1359, 1362-64 (5th Cir 1971) (enjoining airlines' attempt to transfer pilot base from New Orleans to El Salvador); United Industrial Workers v Board of Trustees of Galveston Wharves, 351 F2d 183, 189-92 (5th Cir 1965) (enjoining carrier's effort to lease its facility to another company and permamently lay off all its employees).

${ }^{287}$ For example, in Air Line Pilots $v$ Wien Air Alaska, 120 Labor Rel Ref Man (BNA) 3388 (D Alaska 1984), a district court ruled that a carrier could not close down its operation and furlough its pilots for administrative reasons because such an action was not within its agreed-upon past practices. Id at 3391. In contrast, in Conrail, the Supreme Court ruled that a railroad could unilaterally institute random drug screening of employees because the union had permitted the company to institute other forms of medical testing in the past. $109 \mathrm{~S} \mathrm{Ct}$ at 2485-89. See Stone, $42 \mathrm{Stan} \mathrm{L}$ Rev at 1518-22 (cited in note 218) (discussing Conrail).
} 
this intrusion, courts can and do inject public employment values and policies into the unionized workplace. Thus, while the RLA does not eliminate the tension between collective bargaining and individual employment rights, it does make it possible for those rights to inform the resolution of disputes.

2. Expanded bargaining within a nexus of contracts.

There is another model of collective bargaining which does not share the assumptions of industrial pluralism. I call it an expanded bargaining model. In this model, labor is one stakeholder in the firm among others, free to contend and bargain with the others for a role in decisionmaking. This model eliminates the barrier between collective bargaining and external law.

Traditional theories of the firm assume that shareholders are the only group with a stake in major corporate decisions. Under this view, labor contracts with the firm, but is not a part of the firm. ${ }^{268}$ Further, labor's contracts with the firm are not quite the same as those of other groups who do business with the firm. Labor's contracts take the form of collective bargaining agreements and are governed by a special body of law, the NLRA, which determines what subjects can be included in those contracts and the rules by which they are negotiated.

However, there are new theories of the corporation that give a much more rich and complex picture of the interests of corporate actors, and which advocate a broader view of corporate governance. In a pathbreaking 1976 article in corporate law theory, Jensen and Meckling proposed that a corporation consists of nothing more than a bundle of contractual arrangements among a variety of parties-customers, suppliers, lenders, investors, managers, and workers. ${ }^{209}$ With this insight, the black box view of the corporation collapsed, and the "nexus of contracts" view was born.

Under the nexus of contracts view, no group has an a priori privileged relation to the entity as a whole. All use their input and their leverage to strike the best bargain they can. Thus labor stands on an equal footing with all other contenders for power

${ }^{288}$ See Victor Brudney, The Independent Director-Heavenly City or Potemkin Village?, 95 Harv L Rev 597, 602-03 (1982); Masahiko Aoki, The Co-operative Game Theory of the Firm 8-9 (Clarendon, 1984).

${ }^{208}$ Michael C. Jensen and William H. Meckling, Theory of the Firm: Managerial Behavior, Agency Costs and Ownership Structure, 3 J Fin Econ 305, 311 (1976). See also R. H. Coase, The Nature of the Firm, in R. H. Coase, The Firm, the Market, and the Law 33 (Chicago, 1988) (reprinted from 4 Economica (Nov 1937)) (arguing that the firm is a substitute for a series of discrete market contractual arrangements). 
within the concern. Under this conception of the firm, for example, we can imagine collective bargaining transposed to the boardroom, where unions can then contend with not only management, but all the other constituent groups that comprise the firm. This expanded bargaining is already occurring in the United States in Chapter 11 bankruptcy reorganization proceedings, where unions sit on creditor committees and negotiate with all the different classes of creditors about the fate of the enterprise. Similar forms of expanded bargaining are occurring in troubled industries. ${ }^{270} \mathrm{Col}-$ lective bargaining is beginning to overspill its borders and claim new roles in corporate life.

This model of expanded collective bargaining is fundamentally different from industrial pluralist views of collective bargaining. It does not envision labor-management relations as an insulated mini-democracy. Rather, it permits, even requires, labor to bring to the bargaining table whatever legal rights, powers and immunities it has under external sources of law.

For example, creditors have all sorts of liens, collection procedures, and priorities under state and federal laws. These rights form the background against which creditors make their bargains with other groups within the firm. So too, under the "nexus of contracts" model, if employees have rights under external law, they may use them to exert leverage in their bargaining with the other groups.

Under this conception of collective bargaining, unions would take externally imposed employment rights as the starting point from which to negotiate, the background against which bargaining would take place. Workers would not have to choose between individual employment rights and collective bargaining; the two systems of rights would be compatible and mutually reinforcing. ${ }^{271}$ This regime would help move American labor law in the direction of European labor law, where individual rights and collective bar-

${ }^{270}$ See Stone, $55 \mathrm{U}$ Chi L Rev at 76-77 (cited in note 3) (giving examples).

${ }^{271}$ Of course, such a model requires careful consideration of the rules governing economic weapons. In this model, unions only have clout in negotiations with other constituents of the firm to the extent that unions can bring a credible threat of withholding their investment and thereby harming the others. The ability to withhold investments and the consequence to others-the "negative market power" of unions-is determined by the legal rules governing strikes, secondary boycotts, picketing, and so forth. Thus this model is incomplete without specifying the rules of economic warfare. 
gaining are mutually reinforcing aspects of the social welfare state. $^{272}$

C. Section 301 Preemption, Industrial Pluralism, and Union Decline

If we are to imagine any alternative regime of collective labor rights, we must again consider the issue of union decline. If unions are declining to the vanishing point, then any legal regime based on collective employment rights is outdated before it begins. In Part I, I presented several theories of union decline, and argued in favor of the view which attributed union decline to a decline in the actual and perceived effectiveness of unions. One of the most important factors in explaining union effectiveness is the legal rules which define the legitimate scope of union activity. In Part II, I showed that, over the past decade, there have been many changes in legal rules which have restricted the power of unions to affect strategic-level corporate decisions. These changes no doubt diminish union effectiveness in actuality and in the public mind. We can see now that Section 301 preemption might also play a role in union decline.

To the extent that unionized workers have fewer rights than nonunion workers, $\S 301$ preemption has created significant disincentives for workers to unionize. While most workers, like most judges and law professors, are not familiar with the intricacies of $\S 301$ preemption doctrine, it is entirely plausible than many workers have a general sense that state employment law offers as many or more benefits than do unions. Furthermore, employers frequently inform their employees during organizing drives that they will lose various state law rights if they form a union. Under existing preemption rules, these claims are true. Thus if workers believe such employer claims, and if the claims influence workers'

\footnotetext{
${ }^{272}$ See Maier, Fictitious bonds at 54-55 (cited in note 234). Labor relations scholarship in this country has not adequately addressed the problem of harmonizing individual employee rights with collective employee rights. Instead, most scholars in the field have staked out a position in favor of one type of right and against the other. However, legal scholars writing in another contexts have suggested ways to reconceive both types of rights as complementary. See, for example, Ronald R. Garet, Communality and Existence: The Rights of Groups, 56 S Cal L Rev 1001 (1983) (suggesting ways that group rights and individual rights can be conceived as complementary); Gregory S. Alexander, Dilemmas of Group Autonomy: Residential Associations and Community, 75 Cornell L Rev 1 (1989) (suggesting that both individual and group rights must be understood as limited by a shared commitment to certain external norms).
} 
decisions about whether or not to unionize, then the broad $\S 301$ doctrine is a significant factor in union decline.

\section{ConCLusion}

To conclude, the labor relations system in the United States is undergoing a fundamental change. At the present time, the system of collective worker empowerment established during the New Deal stands in opposition to an emerging system based on individual worker rights, due in large part to an unnecessarily broad § 301 preemption doctrine. As a result, unions have declined in numbers and in political power, endangering collective as well as individual employment rights. I have attempted to show the fault lines in the New Deal system of collective regulation that enabled this new structure to emerge. I have also offered two alternative nonpluralist legal regimes of collective bargaining in order to demonstrate that it is possible to harmonize individual and collective rights. Either would be a form of regulation that could promote a revitalized labor movement into the next century. Without some program, we risk a future with a workforce that is disorganized, disempowered, and disenfranchised. 